
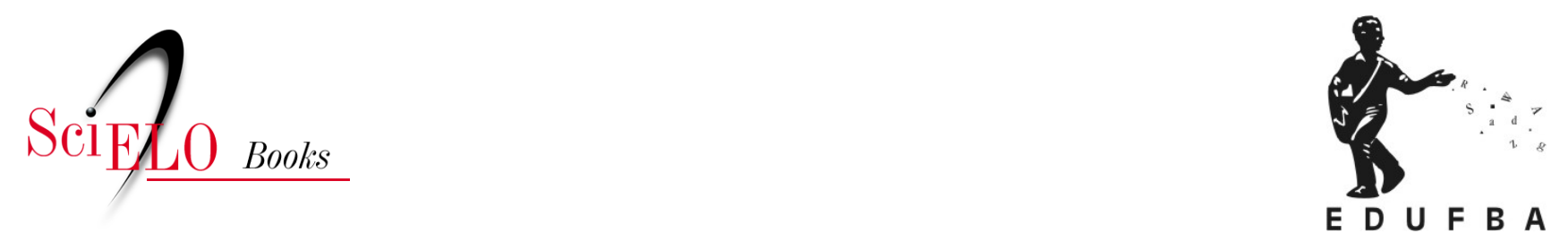

\title{
Parte I - Fundamentos teóricos Questões sociocientíficas e dimensões conceituais, procedimentais e atitudinais dos conteúdos no ensino de ciências
}

\author{
Dália Melissa Conrado \\ Nei Nunes-Neto
}

\section{SciELO Books / SciELO Livros / SciELO Libros}

CONRADO, D.M., and NUNES-NETO, N. Questões sociocientíficas e dimensões conceituais, procedimentais e atitudinais dos conteúdos no ensino de ciências. In: CONRADO, D.M., and NUNESNETO, N. Questões sociocientíficas: fundamentos, propostas de ensino e perspectivas para ações sociopolíticas [online]. Salvador: EDUFBA, 2018, pp. 77-118. ISBN 978-85-232-2017-4. https://doi.org/10.7476/9788523220174.0005.

All the contents of this work, except where otherwise noted, is licensed under a Creative Commons Attribution 4.0 International license.

Todo o conteúdo deste trabalho, exceto quando houver ressalva, é publicado sob a licença Creative Commons Atribição 4.0. 


\title{
QUESTÕES SOCIOCIENTIIFICAS E DIMENSÕES CONCEITUAIS, PROCEDIMENTAIS E ATITUDINAIS DOS CONTEÚDOS NO ENSINO DE CIÊNCIAS
}

\author{
Dália Melissa Conrado \\ Nei Nunes-Neto
}

\section{Introdução}

Diante de tantos problemas socioambientais que têm sido vivenciados no mundo contemporâneo (associados a doenças - como dengue e zika -, mudanças climáticas, perda de biodiversidade, altos níveis de insegurança social, desigualdades socioeconômicas e de acesso a direitos sociais etc.), cabe considerar quais têm sido (isto é, uma análise descritiva) e quais devem ser (isto é, uma proposta normativa) os papéis ou as contribuições da educação, em geral, e da educação científica, em particular, para os contextos sociais mais amplos nos quais elas se inserem.

Uma vez que os sistemas educativos (com seus diversos agentes em interação, como estudantes, professores, diretores de escola, entre outros) sempre estabelecem relações com os problemas socioambientais, seja contribuindo para seu agravamento ou para sua mitigação, não é razoável o discurso de uma postura "supostamente" neutra (ou indiferente) com relação a estes problemas. (TAN, 2009) Dado que os seres humanos individualmente ou em agrupamentos coletivos, em maior ou menor grau, com maior 
ou menor explicitude - sempre se inclinam a favor ou contra certa posição ética e política, o que se manifesta pela emissão de juízos valorativos - as instituições e as práticas humanas carregarão sempre esta marca. Com a educação não é diferente. Disso segue como já nos advertia Paulo Freire (1996) - que não é possível neutralidade na educação. A própria expectativa de neutralidade da educação com relação aos problemas socioambientais consiste numa contribuição para manutenção do status quo, pois uma educação que se pretenda neutra, por omissão, contribui para a manutenção dos problemas tal como eles estão. Por exemplo, uma educação que pretenda manter-se neutra em relação às questões de gênero, por não abordar o sexismo explicitamente nos processos de ensino e aprendizagem (exemplo, em discussões sobre consideração moral, alterização, violência de gênero, identidade sexual e determinismo genético) e nas políticas educacionais (por exemplo, com a inclusão desse tema no currículo escolar), é uma educação que exclui ou negligencia o tema do universo escolar/acadêmico. Uma vez que ainda não há equidade na convivência social entre pessoas de diferentes gêneros, em diferentes contextos, tal omissão contribui para a perpetuação de práticas sociais que aumentam a gravidade do problema em foco, como maior frequência de eventos de preconceito ou segregação de gênero, manifestados concretamente nos atos violentos contra mulheres, por exemplo.

Em particular, cabe notar que a assunção desta suposta neutralidade na educação é comum na perspectiva pedagógica tradicional. Aqui, seguindo Aranha (2006), entendemos educação "tradicional" como aquela que (sendo predominante desde a popularização das escolas, na Idade Moderna, nos séculos XVI e XVII, no Ocidente, associada a ordens religiosas) mantém um grupo de conhecidas estratégias e métodos de ensino consolidados e que ainda persistem atualmente em muitas salas de aula. Algumas características gerais da educação tradicional, principalmente quanto à sua organização social, são: a disposição enfileirada das carteiras dos estudantes; o uso de um sinal sonoro para indicar mudança de disciplina (com analogia ao sinal de fábrica que indica mudança de turno); a autoridade para a transmissão ativa do conhecimento centrada no professor; a obediência e a passividade como características desejadas no estudante; a homogeneização dos êxitos, expressos no alcance da memorização de conceitos etc. Por sua vez, em particular, a educação científica sob uma perspectiva da abordagem tradicional (também considerada aqui como educação científica tradicional-tecnicista, pois, no ensino de ciências, é predominante o ensino de técnicas e procedimentos) pode ser descrita a partir das seguintes características: ênfase na transmissão de conhecimentos científicos consolidados culturalmente - isto é, educação bancária, conforme Freire (1996) -; descontextualização social e ambiental - isto é, que não considera, ao menos não explicitamente, a ciência como uma atividade humana relacionada a um contexto sociocultural e ambiental mais complexo e abrangente, no qual há influências mútuas entre ciência, tecnologia, sociedade e ambiente -; conceitualismo - isto é, predomínio de exposição, pelo professor, e memorização, pelos estudantes, de fatos, termos e 
definições científicos, os quais são assumidos como o verdadeiro objeto da educação, em detrimento de aprendizagem de valores, normas e atitudes -; e tecnicismo - isto é, predomínio de apresentação e reprodução de procedimentos técnicos e experimentos científicos, em detrimento de valores, normas e atitudes presentes na ciência e na tecnologia. Em suma, tal educação assume como seu objetivo a transmissão eficiente (pelo professor) e a suposta aprendizagem (pelo estudante) de informações acumuladas ao longo da história e, por isso mesmo, não deixa espaço para um incentivo à crítica, à criatividade ou à reflexão sobre valores, ideologias e contextos relacionados à ciência $\mathrm{e}$ à tecnologia. (ARANHA, 2006; BARRETT; PEDRETTI, 2006; CONRADO; EL-HANI, 2010; FOUREZ, 2008, 1995; HODSON, 2004; KNIGHT; WOOD, 2005; MARTÍNEZ PÉREZ; CARVALHO, 2012; MATTHEWS, 1994)

A crítica que fazemos à educação científica tradicional-tecnicista precisa ser colocada de modo qualificado. Isto significa reconhecer que as estratégias de ensino da abordagem tradicional-tecnicista não são inadequadas, em absoluto, para a aprendizagem de fatos, conceitos e técnicas. Contudo, o predomínio dessas estratégias e dos modelos de ensino baseados na abordagem tradicional-tecnicista no meio escolar/acadêmico tem dificultado o cumprimento de muitos dos objetivos educacionais estabelecidos para a educação científica, pois apenas reproduz modelos e ideologias dominantes do sistema social vigente (FOUREZ, 2008; LUCKESI, 2011), reduzindo a contribuição da escola/ academia para a criatividade, a criticidade, o diálogo, a tomada de decisão informada e possíveis transformações positivas das sociedades, em relação a seus problemas, tais como os citados acima. Isso significa que, para formar cidadãos capazes de mobilizar, nas práticas cotidianas, determinados conhecimentos, habilidades e valores voltados à superação de problemas socioambientais em sociedades democráticas, a educação tradicional-tecnicista, apesar de conter elementos que oferecem contribuições positivas, não é suficiente. (BORTOLETTO; CARVALHO, 2012; HODSON, 2004)

Contudo, não é suficiente, também, fomentar uma educação para a democracia, quando não se esclarecem os valores presentes nos diversos grupos sociais e que valores devem ser fomentados em detrimento de outros. Este não esclarecimento pode levar, por exemplo, à aceitação acrítica de raciocínios contraditórios, pois inadvertidamente podem-se assumir bases éticas (em termos dos fundamentos teóricos sobre ações e valores) incompatíveis com certos ideais sociais. Trata-se de assumir, por escassez de uma reflexão crítica sobre valores, uma incompatibilidade entre, de um lado, os fundamentos e os meios (isto é, as bases éticas, nos valores e ações) e, de outro, os fins (isto é, os ideais sociais a serem alcançados). Por exemplo, uma democracia que - com base em certos fundamentos ideológicos - privilegie ações como o individualismo, a competição, a alterização, a manipulação, o consumismo, fundamentadas em uma tendência ética egoísta e concretizadas numa maior valorização do bem privado sobre o bem público, é incompatível com os fins de justiça social e sustentabilidade ambiental, ideais, via de regra, associados a maior altruísmo. (SINGER, 2011) Tal incoerência entre fun- 
damentos, meios e fins pode, até mesmo, nos fazer desconfiar da própria efetividade da democracia, nestes casos, que pode não passar de uma democracia meramente formal, longe, ainda, da democracia real (SAVIANI, 1987), esta última um regime em que os representantes e os representados, de fato, em suas ações, sejam orientados pela vontade e pelos interesses da maioria, ao invés de serem orientados por interesses sinistros.

O altruísmo tem relação com um conjunto de valores que precisa ser mais fomentado, seja nas relações sociais em geral, seja nas instituições de ensino, em particular. Neste sentido, valores associados ao altruísmo, como respeito, solidariedade, comprometimento com a política local, justiça e não-violência, estão vinculados à aprendizagem e ao exercício da cidadania. (LODI; ARAÚJO, 2007) Para isso, Sadler (2004a), Zeidler e colaboradores (2005), Lodi e Araújo (2007), Guimarães; Carvalho e Oliveira (2010); Conrado; El-Hani; Nunes-Neto (2013); Silva e Santos (2014) e outros enfatizam a importância do desenvolvimento moral do estudante. Além disso, faz-se necessária também, em articulação com uma educação moral, uma educação política efetiva, já que, sem esse estímulo na educação, os cidadãos podem se tornar politicamente apáticos e não participativos. (PINZANI, 2013)

Tentativas de superação dos problemas da educação científica tradicional-tecnicista têm acontecido em diversas frentes de atuação, por diferentes atores sociais. Por exemplo, alguns têm recomendado investir na qualidade da formação de professores que atuarão ou atuam na educação científica (MARTíNEZ PÉREZ, 2012); outros, na elaboração colaborativa de materiais instrucionais, sequências didáticas e recursos pedagógicos (MARTÍNEZ PÉREZ; VILLAMIZAR FÚQUENE, 2014; SÁ; QUEIROZ, 2007; SARMENTO et al., 2013; VELLOSO, 2009); além das ações para a promoção de mudanças em nível jurídico ou político. (BRASIL 1997, 1998) Certamente, tais recomendações não são mutuamente excludentes, sendo razoável imaginar que uma solução mais profunda e duradoura para aumentar a qualidade dos processos de ensino e aprendizagem, assim como da formação de professores e estudantes críticos e participativos, dependa de uma articulação equilibrada e consciente de diversas destas frentes de atuação, em esforços coletivos, de longo prazo.

Neste âmbito, no presente capítulo, apesar das referências às diferentes frentes de atuação, colocaremos nossa ênfase sobre as bases teóricas de uma abordagem de educação científica contextualizada por problemas socioambientais, objetivando uma formação mais crítica e integral dos estudantes. Assim, o objetivo deste capítulo é apresentar um modelo para a educação científica alternativo ao modelo tradicional-tecnicista e fundamentado na educação em Ciência, Tecnologia, Sociedade e Ambiente (CTSA), voltado para o ensino sobre Questões Sociocientíficas (QSC), considerando os conteúdos em três dimensões (conceituais, procedimentais e atitudinais). Um esboço do modelo, que aqui apresentamos, serviu como base para as propostas de ensino que são apresentadas na parte dois deste livro. 
Para alcançar o objetivo, discutiremos e articularemos uma série de temas distintos, estruturando o argumento do capítulo do seguinte modo: na seção "Tendências da educação CTSA”, exporemos as características da educação sobre as relações entre CTSA e como ela, pelo menos em potência, supera limitações importantes da educação científica tradicional-tecnicista. Na nossa proposta, certas vertentes da educação CTSA constituem um contexto pedagógico geral dentro do qual as propostas de ensino e aprendizagem terão lugar. Na seção seguinte, abordaremos as questões sociocientíficas, cujo tratamento em propostas de ensino permite concretizar ideais ou objetivos de formação de cidadãos responsáveis, já vislumbrados ou situados pelas vertentes que adotamos da educação CTSA. Na seção "Aprendizagem de ciências considerando três dimensões dos conteúdos”, apresentamos o esboço para uma abordagem dos conteúdos científicos, que, possivelmente, estende-se para conteúdos da educação como um todo. Esta abordagem concebe os conteúdos (isto é, os objetos dos processos de ensino e aprendizagem) de um modo multidimensional. Em particular, concebemos os conteúdos com três dimensões: conceitual, procedimental e atitudinal, e seus respectivos subtipos, seguindo, mas também elaborando sobre, a tipologia de Zabala (1998) e Coll e colaboradores (1992). A partir do exposto, construiremos uma síntese da nossa abordagem, na qual as propostas de ensino sobre QSC são compostas de três elementos principais, articulados: histórias ou casos, questões norteadoras e objetivos de aprendizagem, nas suas diferentes dimensões. Ainda nessa seção, discutiremos um modo de avaliar essas diferentes dimensões dos conteúdos, considerando os níveis de letramento científico de Hodson (2004), a relevância da dimensão ética na educação científica e o potencial deste movimento para o fomento de ações sociopolíticas e ativismo, de acordo com nossa abordagem. Por fim, na última seção, lançaremos nossas considerações finais.

\section{Tendências da educação CTSA}

Desde seu surgimento, na década de 1960, o movimento Ciência, Tecnologia e Sociedade (CTS), de acordo com Von Linsingen (2007), esteve associado a três principais campos: primeiro, à pesquisa acadêmica, seguindo uma mudança da concepção de ciência e tecnologia e sua relação com a sociedade, com destaque para críticas ao positivismo clássico; segundo, às políticas públicas, com a promoção de maior participação da população sobre questões sociais, envolvendo ciência e tecnologia; e terceiro, à educação, com a defesa de programas e currículos orientados para as relações entre ciência, tecnologia e sociedade, capazes de formar cidadãos aptos para compreender e controlar o desenvolvimento científico e tecnológico. (VON LINSINGEN, 2007)

Aqui cabe notar que, apesar de algumas considerações sobre o ambiente estarem presentes no surgimento da crítica à educação científica tradicional-tecnicista, entre as décadas de 1960 e 1970 (para isto, basta notar os movimentos de educação ambien- 
tal e do próprio ambientalismo, nos anos 1960 e 1970), a inclusão explícita de uma dimensão ambiental, nos estudos que relacionam ciência, tecnologia e sociedade, passa a ser defendida por alguns autores preocupados com a gravidade da crise ambiental, apenas mais recentemente. (PEDRETTI; FORBES, 2000; VILCHES; GIL-PÉREZ; PRAIA, 2011) Vilches, Gil-Pérez e Praia (2011), por exemplo, defendem a inclusão do A, de ambiente, resultando na expressão CTSA, em razão de que não é suficiente assumir que considerações sobre o ambiente já estão, diretamente, presentes quando falamos da sociedade. Concordamos com esses autores no sentido de que é preciso reconhecer explicitamente o ambiente como um elemento em relação com CTS, pois o Ambiente - através dos seus componentes bióticos (animais, plantas, microrganismos etc.) e abióticos (oceanos, rios, lagos, montanhas, atmosfera, solos etc.), por exemplo - é a própria condição de possibilidade natural para qualquer sociedade. Afinal, trata-se de reconhecer uma obviedade, inconveniente para os processos produtivos predatórios do capitalismo atual, mas absolutamente necessária: a natureza ou o ambiente impõe limites - e não apenas oferece "recursos" - às sociedades (MEADOWS et al., 1972; WWF, 2014; MEADOWS et al., 1972) e estes limites naturais precisam ser respeitados. Pelas razões expostas, daqui em diante, utilizaremos apenas a expressão CTSA para nos referirmos tanto ao movimento CTSA quanto ao CTS.

No âmbito do movimento CTSA, a educação sob esta perspectiva (educação CTSA) busca, a partir de maior contextualização, interdisciplinaridade e criticidade, alcançar um ensino mais humanitário e menos tecnocrático, em especial no âmbito da educação científica e tecnológica. (AULER; BAZZO, 2001; AULER; DELIZOICOV, 2006; VON LINSINGEN, 2007) Pretende-se que as situações (que contextualizam os conteúdos científicos) contribuam para o aumento do interesse e o reconhecimento da importância desses conteúdos pelos estudantes para a solução de problemas do seu próprio cotidiano. (TORRES-MERCHÁN, 2011)

Quando falamos em educação CTSA, pode parecer que estamos nos referindo a um movimento coeso na educação, sem divergências internas, sem diferentes enfoques, ênfases ou tendências. Pedretti e Nazir (2011) nos ajudam a entender melhor este ponto e mostram que tal coesão não é necessariamente o caso. As autoras ofereceram uma contribuição importante para o entendimento da diversidade de abordagens sob o rótulo de CTSA, do ponto de vista do foco, dos objetivos da educação científica, das abordagens dominantes e, ainda, das estratégias de cada vertente mobilizadas para aplicar a educação CTSA. Em sua análise sobre o desenvolvimento do movimento CTSA na educação, Pedretti e Nazir (2011) descrevem a existência de seis vertentes ou tendências da educação CTSA que se estabeleceram nos últimos 40 anos e, ainda, apontam algumas objeções, na literatura, dirigidas a cada uma delas. Embora essas vertentes não sejam mutuamente excludentes, nem a análise das autoras se pretenda exaustiva, como elas próprias reconhecem, essa caracterização pode auxiliar na compreensão de um pano- 
rama geral das tendências da educação CTSA. Cabe então analisar tal panorama, pois é dentro dele que situaremos, mais claramente, nossa abordagem.

A primeira vertente, de acordo com Pedretti e Nazir (2011), tem foco na aplicação dos conhecimentos científicos e tecnológicos na resolução de problemas sociais do cotidiano. A principal crítica a essa vertente, segundo as autoras, relaciona-se ao estímulo a uma ideia de que a ciência e a tecnologia são imprescindíveis para resolver problemas sociais, gerando, principalmente, uma dependência tecnológica do estudante/cidadão, o que seria uma visão pouco crítica acerca dos problemas socioambientais. Exemplos de trabalhos e autores nesta vertente são: Solomon (1993) e Layton (1988). A segunda categoria apresentada pelas autoras destaca o aspecto histórico e sociocultural da ciência e sua conexão com a compreensão da atividade científica no contexto social interno à própria ciência. A principal crítica a esta vertente está no estímulo a uma visão de ciência desconexa de um contexto social mais amplo, externo à própria ciência, como, por exemplo, os problemas socioambientais atuais, podendo reforçar estereótipos ou histórias mainstream, isto é, dominantes, tanto acerca da ciência, quanto de outras formas de conhecimento. Alguns autores que podem ser situados nesta vertente são: Matthews (1994) e Ziman (1994). Na terceira vertente, prioriza-se o raciocínio lógico e a argumentação. Para alguns autores - por exemplo, Jiménez-Aleixandre; Pereiro-Muñoz (2002) -, tais elementos são muito relevantes e acreditamos que, por isso mesmo, precisam estar cada vez mais presentes nas salas de aulas, sobretudo por contribuições que podem oferecer para o desenvolvimento do pensamento crítico dos estudantes. Contudo, tal vertente tem sido criticada por superestimar aspectos epistemológicos, não reconhecendo outros fatores relacionados à tomada de decisão, como emoções e valores. Segundo as autoras, a priorização sobre técnicas de comunicação e organização do pensamento, na educação científica, presente nesta vertente, pode reduzir a sensibilidade e gerar alienação (a aspectos não epistemológicos) nos estudantes. Driver, Newton e Osborne (2000), Osborne, Eduran e Simon (2004) e Jiménez-Aleixandre e Frederico-Agraso (2006) são alguns exemplos de trabalhos nesta vertente.

As próximas vertentes se desenvolveram a partir das críticas às primeiras. A quarta está centrada no reconhecimento dos valores relacionados à ciência, com ênfase sobre os aspectos éticos e ao desenvolvimento cognitivo e moral do estudante. As críticas a essa vertente estão associadas à ideia de relativismo ético e à necessidade de se estabelecer um consenso global de valores. Zeidler e Keefer (2003) e Sadler (2004a, 2004b) são alguns trabalhos de representantes desta vertente. Por sua vez, a quinta vertente enfatiza aspectos socioculturais da ciência e da tecnologia, sendo estas compreendidas como parte da sociedade e integradas às atividades políticas, econômicas e culturais. A desvalorização do conhecimento científico é uma das principais críticas, devido à consideração, por igual, na sala de aula, de múltiplos contextos culturais. Exemplos de trabalhos nesta vertente são os de Carter (2008) e Brown-Acquaye (2001). Por fim, a última vertente refere-se à formação de ativistas, no sentido de cidadãos capazes de agir 
para transformar a sociedade em direção a maior justiça social e ambiental. Para isso, a educação científica deve explicitar: as influências mútuas entre política, economia e ciência; os fundamentos dos juízos morais; além de desenvolver responsabilidade cívica e pensamento crítico para a realização de ações sociopolíticas que, muitas vezes, ultrapassam os limites físicos da escola. As críticas a essa vertente referem-se à relativização do que seria justo, bom e correto, além da própria adoção de um tipo de democracia como forma padronizada de organização da sociedade. Outra objeção seria no sentido da adoção de um framework filosófico específico (como, por exemplo, a teoria crítica ou as correntes pós-estruturalistas) para justificar a necessidade de empoderamento e emancipação do cidadão, o que excluiria outros frameworks filosóficos da educação, com propósitos distintos, como o de obediência às tradições culturais e a manutenção do status quo. Trabalhos e autores relevantes desta vertente são os de Reis (2013), Hodson (2004, 2011) e Bencze e Alsop (2009), entre outros.

Ainda que possamos considerar contribuições positivas de outras vertentes, a abordagem que apresentamos neste capítulo é preponderantemente alinhada com a quarta e a sexta vertentes, da análise de Pedretti e Nazir (2011). Por isso, dedicaremos mais espaço a responder a críticas levantadas a tais vertentes.

Assim, consideremos, inicialmente, a quarta vertente. Com relação às objeções de que normas éticas (associadas ao que se considera bom, justo e correto) são relativas e, também, sobre a dificuldade de estabelecer um consenso global de valores, acreditamos que podemos responder com base em reflexões provenientes da filosofia moral. A esse respeito, Rachels (2006), ao discutir os problemas associados à assunção de um relativismo ético, aborda que uma das origens da ética está relacionada ao controle da violência entre os seres humanos que viviam em grupos e, dessa forma, há critérios universais para o estabelecimento de regras morais que independem de códigos morais de diferentes culturas, o que se configura como condição de possibilidade para a convivência social: segundo o autor, a prática social que não cause danos e sofrimento a quem é afetado por ela. Para Rachels (2010), este é um padrão ético independente de cultura, porque considera o valor intrínseco da vida dos envolvidos, de modo a determinar padrões de certo e errado que estão presentes nas diferentes tradições culturais. Assim, apesar de J. Rachels e S. Rachels (2014) assumirem a possibilidade de um relativismo cultural, isso não significa assumir um relativismo ético, uma vez que muitas práticas culturais são apenas convenções sociais e, portanto, produtos culturais, que podem mudar com a transformação da sociedade, ao longo do tempo; já os critérios universais, que estão no surgimento e na "razão de ser" da ética, estes não são meras convenções sociais e muitas vezes são a base de valores para determinadas tradições. Dito de outro modo, um problema da relativização da ética em relação aos padrões culturais está em assumir que os critérios para o que se deve fazer são dados pela cultura, não por algum padrão supracultural. Nesse sentido, aquele que defende uma relativização do certo e do erra- 
do, do que se deve e do que não se deve fazer, somente com base na cultura, precisaria responder, assim, duas difíceis questões:

- como justificar relações de opressão, ou até mesmo de violência física, que, historicamente, fazem parte de certas culturas? Por exemplo, seria correto permitir a clitorectomia, isto é, a retirada do clitóris, em algumas regiões, com base no fato de que isto é parte de uma tradição cultural, mesmo sabendo que as vítimas desse procedimento sentem dores e são susceptíveis a infecções e sofrimento, por conta de determinados costumes? Outro exemplo ilustra o mesmo ponto: seria correto continuar a permitir touradas, nos países onde ocorrem, porque isto é parte de uma tradição cultural, mesmo sabendo que as vítimas dessa atividade sentem dores e são submetidas a grande estresse e sofrimento, pelo entretenimento humano? Se o certo e o errado fossem relativos à cultura, não poderíamos fazer nenhum juízo moral sobre a cultura alheia e nem sobre o que consideramos errado nas tradições de nossa própria cultura, da mesma forma que não poderíamos condenar moralmente as duas práticas acima;

- se aceitarmos que as culturas já possuem, internamente, os critérios para o julgamento do certo e do errado, do que devemos ou não fazer, então não seria possível, por definição, encontrarmos critérios comuns a diferentes culturas, portanto, trans ou supraculturais, pois isto envolveria uma contradição, uma vez que cada critério seria totalmente particular e único de uma determinada cultura. E isso, de fato, não ocorre. Em outras palavras, ao relativizar o juízo moral com base na cultura, em geral, se assume uma representação das culturas como entidades isoladas, no sentido que cada cultura teria seus próprios critérios para determinação de certo e errado. O equívoco dessa representação estaria na simplificação excessiva da complexidade cultural, desconsiderando critérios para atribuição de juízo moral que são compartilhados entre diferentes culturas. Assim, nesse sentido, será que não existiriam padrões que transcendem ou abrangem diferentes culturas, que se baseiem em nossas similaridades enquanto seres humanos ou enquanto seres que devem ser moralmente considerados? Por exemplo, a violência contra uma mulher brasileira é um erro, precisamente, porque é parte de uma cultura ou porque é um ato de violência, que desrespeita um direito básico, que é o direito de não ser agredido (ou não sofrer nenhum tipo de violência), seja no Brasil, seja em qualquer outro país do mundo?

Parece-nos mais razoável pensar, contra um relativismo ético, seguindo a Rachels (2006), assumindo que as manifestações culturais, no que dizem respeito ao que devemos fazer são, muito mais, instanciações nas diversas culturas específicas, com todas as riquezas, os vieses e as dinâmicas, que estas apresentam, de padrões morais mais amplos, que, em última instância, são éticos e transcendem as culturas. 
Por sua vez, com relação às críticas à sexta vertente, que se aproximam das críticas à quarta, cabe notar que será a partir de uma reflexão ética e política adequada que poderemos definir o justo, o bom e o correto. Recomendamos realizar tal reflexão a partir da filosofia moral, que oferecerá critérios para decidir sobre os ideais mencionados (como exemplificaremos ao final do capítulo, para um caso), o que implicará assumir explicitamente certas posições políticas. Assim, o mais importante, neste ponto, nos parece, é o estabelecimento de critérios claros para definir o bom, o justo e o correto, entendendo que a adoção de um critério claro, de um certo ponto de vista, com certos interesses, como não poderia deixar de ser, por tratar-se de discussões filosóficas, não excluirá a possibilidade de novas visões, de novos critérios, potencialmente divergentes. Com relação à objeção que aponta para uma aparente tensão entre empoderamento e emancipação, de um lado, e a adoção de um framework teórico específico, de outro, acreditamos que ela não seja, de fato, problemática, desde que se aceite a perspectiva de uma relação dialética - e assim, possivelmente, tensionada - entre a teoria filosófica específica, subjacente, e a prática social (práxis) do empoderamento, da reflexão e do ativismo. Afinal, não há razão para supor que os verdadeiros empoderamento e emancipação humanos dependerão da existência de uma teoria prévia que lhe dê sentido, como condição de possibilidade, e ainda o faça de modo completamente harmônico. De certa forma, nos parece mais profícuo explorar as possíveis contribuições mútuas entre teoria e prática social. Neste sentido, a prática do pensamento crítico em sala de aula, com todas as possibilidades filosóficas que lhe fundamentam, parece ter um papel muito relevante, uma vez que é uma manifestação da emancipação e do empoderamento, com relação aos problemas (como os que temos apontado).

Além disso, a própria explicitação de ideologias, fundamentos filosóficos e valores é um pressuposto necessário para compreender e esclarecer as finalidades da educação e, a partir disso, assumir compromissos e métodos condizentes com a formação pretendida para o sujeito. Nesse contexto, a formação de cidadãos capazes de agir em favor de maior justiça social e sustentabilidade ambiental tem sido apontada como um importante objetivo da educação científica, conhecida como letramento científico crítico. (BENCZE, 2014; CONRADO; NUNES-NETO; EL-HANI, 2016; HODSON, 2011)

Como bem notam Barrett e Pedretti (2006), a educação CTSA, por si mesma, não é uma educação transformadora, uma vez que ela se apresenta concretamente dentro de uma ou mais vertentes, as quais possuem objetivos diferentes. Além disso, uma educação CTSA pode ser implementada muito mais para manter o status quo social e político do que para promover mudanças efetivas rumo a maior igualdade, justiça e sustentabilidade. Contudo, pensamos que, na educação CTSA, a promoção do letramento científico deve estar alinhada a uma educação transformadora, tomando como inspiração a pedagogia crítica de Paulo Freire (BARRETT; PEDRETTI, 2006; FREIRE, 1996; SANTOS, 2009), no sentido de superar a mera transmissão das informações sobre CTSA. Assim, uma educação CTSA orientada para a transformação social positiva deve promover con- 
dições para que os estudantes avaliem criticamente valores e interesses das estruturas sociais, engajando-se em ações para a promoção de uma sociedade mais justa e ambientalmente mais sustentável. Isso significa ampliar o escopo da educação científica, em um contexto interdisciplinar e voltado aos problemas socioambientais atuais.

De um modo geral, apesar de suas particularidades, em todas as suas vertentes, o enfoque da educação CTSA na educação científica tem permitido uma melhor compreensão dos papéis docentes e discentes voltados ao "[...] desenvolvimento de atitudes e valores correspondentes à compreensão da ciência como uma atividade cultural" (MARTÍNEZ PÉREZ; PARGA LOZANO, 2013, p. 25), combatendo os denominados mitos do cientificismo (CONRADO; EL-HANI, 2010; CONRADO; CONRADO, 2016a, 2016b; SANTOS; MORTIMER, 2002), assim como possibilitou a integração explícita de aspectos éticos e políticos no ensino de ciências. Neste contexto, uma reorganização curricular é necessária, e estratégias de ensino inovadoras, como as voltadas ao ativismo e a ações sociopolíticas, têm sido propostas e desenvolvidas nos últimos anos a fim de atender a estas demandas. (BENCZE; CARTER; KRSTOVIC, 2014; MARTÍNEZ PÉREZ, 2012; REIS; NG-A-FOOK; GLITHERO, 2015; REIS, 2013, 2014) O método que propomos neste capítulo, para aplicar pressupostos da educação CTSA, inspira-se no uso de QSC, o que abordaremos a seguir.

\section{Questões sociocientíficas na educação CTSA}

Um modo de promover a educação CTSA, nas aulas de ciências, é a partir do uso de temas controversos, mais precisamente por meio de QSC. QSC são problemas ou situações geralmente complexos e controversos, que podem ser utilizados em uma educação científica contextualizadora, por permitir uma abordagem de conteúdos inter ou multidisciplinares, sendo os conhecimentos científicos fundamentais para a compreensão e a busca de soluções para estes problemas. Além do conhecimento científico, particularmente, conhecimentos de filosofia (sobretudo de ética) e história são relevantes e geralmente mobilizados na abordagem das QSC, além de diferentes habilidades, valores e atitudes, pois a proximidade com situações do contexto real aumenta o interesse, o diálogo e o engajamento dos estudantes. Quando associado, em alguma medida, às ações sociopolíticas, podemos considerar que o ensino a partir de QSC se classifica como uma metodologia ativa ou participativa. (CONRADO, 2017; SADLER; BARAB; SCOTT, 2007) Bons exemplos de QSC são: aquecimento global, perda de biodiversidade, extinção de abelhas com consequente redução da produção de vegetais, poluição hídrica, racismo, entre outros. As propostas de ensino apresentadas na parte dois deste livro focalizam diferentes QSC.

Ainda, cabe ressaltar que, no intuito de potencializar a aprendizagem sobre algum tema, a conexão afetiva/emocional entre a controvérsia sociocientífica e o estudante é um fator essencial para seu engajamento na resolução do problema e na busca de fer- 
ramentas e conhecimentos relacionados ao tema. (KERCKHOFF; REIS, 2014; SADLER, 2004b) O engajamento e a aproximação afetiva/emocional auxiliam na percepção de que o estudante é um responsável direto e, por isso, capaz de (e necessário para) promover mudanças no sentido de resolver ou mitigar os problemas socioambientais atuais. Nesse sentido, segundo Reis (2013), as QSC são úteis para uma melhor aprendizagem de conteúdos científicos aliados ao desenvolvimento cognitivo e ético dos estudantes.

As QSC podem ser transpostas para o ensino, no âmbito de uma estratégia didática ou um método de ensino que permita aos estudantes mobilizar e aprender sobre determinados conteúdos, de modo contextualizado, assim como compreender criticamente a Natureza da Ciência e desenvolver habilidades relacionadas ao pensamento crítico. (CONRADO; CONRADO, 2016a, 2016b; KRSTOVIC, 2014; MARTÍNEZ PÉREZ; PARGA LOZANO, 2013; SOLBES, 2013) As propostas de ensino baseadas em QSC, quando adotadas como uma estratégia ou um método de ensino, na educação científica, tendem a estar associadas às seguintes características:

- estimulam discussões interdisciplinares sobre um tema, geralmente, veiculado nos meios de comunicação de massa, capaz de promover argumentação (HODSON, 2013; MARTÍNEZ PÉREZ; CARVALHO, 2012);

- explicitam implicações éticas (SADLER; ZEIDLER, 2004) e ambientais (CONRADO, 2013; MARTÍNEZ PÉREZ; PARGA LOZANO, 2013);

- mobilizam conhecimentos científicos de fronteira, bem como aqueles associados à compreensão da Natureza da Ciência (HODSON, 2013; RATCLIFFE; GRACE, 2003; REIS; NG-A-FOOK; GLITHERO, 2015);

- envolvem discussão de valores morais, interesses e opiniões (BERKOWITZ; SIMMONS, 2003; CONRADO, 2013; HODSON, 2004; SADLER, 2004a; ZEIDLER et al., 2005); e por fim,

- possibilitam tomada de decisão e ação dos participantes (HODSON, 2011, 2013; MARTÍNEZ PÉREZ; PARGA LOZANO, 2013; RATCLIFFE; GRACE, 2003).

No âmbito da educação científica formal, sobretudo voltada ao letramento científico crítico, as propostas de ensino baseadas em QSC podem ser utilizadas para desenvolver nos estudantes:

- compreensão e reflexão crítica sobre as relações entre a ciência, a tecnologia, a sociedade e o ambiente, uma vez que se exploram diferentes dimensões e pontos de vista sobre um conteúdo científico (HODSON, 2013; SOLBES, 2013);

- habilidades de busca, seleção, análise, discussão e avaliação de informações sobre um tema controverso, o que envolve o estudante em um processo in- 
vestigativo e de desenvolvimento de habilidades argumentativas (KRSTOVIC, 2014; REIS, 2014; TORRES-MERCHÁN, 2011);

- capacidade de raciocínio moral para avaliar, julgar e se posicionar sobre a situação, a partir da explicitação de valores e diferentes cursos de ação envolvidos (GUIMARÃES; CARVALHO; OLIVEIRA, 2010; TORRES-MERCHÁN, 2011; REIS, 2013; ZEIDLER et al., 2005);

- maior envolvimento e senso de responsabilidade da população sobre o desenvolvimento científico e tecnológico e seus impactos sociais (LEVINSON, 2006; REIS, 2013; SANTOS, 2009);

- oportunidades para que realizem ações sociopolíticase iniciativas de ativismo, o que pode conduzir a transformações de suas identidades enquanto pessoas (BENCZE; ALSOP, 2009; BENCZE; CARTER; KRSTOVIC, 2014; HODSON, 2011, 2013; REIS; NG-A-FOOK; GLITHERO, 2015).

No contexto da aplicação das propostas de ensino baseadas em QSC, a aprendizagem de ciências para a formação de cidadãos mais autônomos e participativos deve considerar não apenas o conhecimento científico, mas também conhecimentos prévios e valores socioculturais do entorno do sujeito. (HODSON, 2004) Por fim, em uma estrutura curricular com base em QSC, pode-se superar uma relação do estudante passivo e receptor de informação com o professor centralizador e transmissor da informação, para uma relação em que o estudante constrói ativamente seus conhecimentos, estimulado para mobilizar dados, teorias, técnicas e valores para a resolução de um problema real, que the interessa. $O$ professor, nessa relação, atua muito mais como um consultor crítico, que orienta e facilita a aprendizagem, além de fornecer apoio emocional e teórico, a partir de atividades de reflexão sobre as informações, sofisticação de argumentos, entre outras. A esse tipo de relação, Hodson (2014) denomina comunidade de aprendizagem, a qual depende, para seu próprio funcionamento, do esclarecimento de regras ou normas sociais como respeito, responsabilidade, tolerância e boa vontade.

Inspirando-nos em Sá e Queiroz (2007), Lima e Linhares (2008) e Velloso e colaboradores (2009), assim como em trabalhos prévios nossos (CONRADO, 2013; CONRADO et al., 2012; CONRADO; EL-HANI; NUNES-NETO, 2015; CONRADO et al., 2015, 2016), nos parece adequado abordar QSC na forma de casos, construídos como histórias curtas, contendo, se possível, diálogos e personagens que se aproximam do(s) contexto(s) sociocultural(is) dos estudantes. A este elemento das propostas de ensino baseadas em QSC, denominamos simplesmente caso ou história.

A organização de uma sequência de eventos na forma de uma história, como no uso de narrativas, é um modo de explicitar diferentes interpretações, pontos de vista, crenças e juízos de valor, além de permitir a aproximação do tema controverso com o estudante, contribuindo para sua sensibilização e seu engajamento. (LEVINSON, 2006; ZEIDLER et al., 2005) Contudo, o caso por si só pode ser mal ou subutilizado 
para o desenvolvimento de habilidades, conhecimentos e atitudes. Deste modo, a fim de mobilizar determinados aspectos dos problemas sociocientíficos presentes no caso, de acordo com nossa abordagem, sugerimos a utilização do que chamamos de questões norteadoras. Estas são, simplesmente, questões, claramente colocadas como perguntas sobre o caso (e/ou sobre aspectos globais que podem estar instanciados no caso) e que demandarão dos estudantes ações condizentes com objetivos de aprendizagem previamente definidos. As questões norteadoras aproximam-se da estratégia, proposta por Fullick e Ratcliffe (1996), de discussões em grupos sobre questões que dirigem, de modo equilibrado, a atenção dos estudantes para a natureza do problema e as possíveis soluções, incluindo um debate crítico acerca dos valores que fundamentam as diferentes soluções. Desse modo, conforme os objetivos de ensino e de aprendizagem, é possível, a partir das questões norteadoras: perceber diferentes complexidades e múltiplas perspectivas; desenvolver argumentos sobre o caso; compreender teorias e conceitos científicos e investigar técnicas e tecnologias relacionadas à QSC; entender implicações e influências de sociedade, política e valores de atores sociais envolvidos; emitir juízos sobre esses atores sociais e consequências socioambientais das diferentes decisões; e, por fim, posicionar-se claramente a respeito da QSC relacionada ao caso e tomar decisões socioambientalmente responsáveis. (CONRADO, 2017)

A estes dois elementos, constituintes da nossa perspectiva, articulamos, ainda, um terceiro, os objetivos de aprendizagem, definidos a partir de uma concepção tridimensional dos conteúdos. Assim, na próxima seção, explicitaremos as relações das QSC com dimensões do conteúdo escolar/acadêmico, em uma perspectiva de educação CTSA.

\section{Aprendizagem de ciências considerando três dimensões dos conteúdos}

Nesta seção, defenderemos que as dimensões Conceituais, Procedimentais e Atitudinais (CPA) dos conteúdos da educação científica são objetos adequados para uma educação científica com base na perspectiva da educação CTSA e que poderão ser buscados a partir da adoção de estratégias ou métodos de ensino (ou, ainda, na estrutura política mais profunda da educação, representada pelos currículos) baseados em QSC. Para isso, apresentaremos uma concepção mais ampla dos conteúdos escolares/acadêmicos, especificamente em três dimensões e que abrangem o desenvolvimento de conhecimentos, habilidades, valores e atitudes essenciais voltados para uma formação mais integral dos sujeitos enquanto indivíduos efetivamente engajados em participação social.

É importante notar que a diferenciação dos conteúdos em suas dimensões CPA é artificial e metodológica, criada para auxiliar na compreensão de um fenômeno complexo, que ocorre de maneira integral - cognitiva, comportamental e socialmente - que é a aprendizagem do conteúdo. De fato, como bem nota Zabala (1998, p. 39, grifo nosso), ao invés de ser a realidade tal como ela é, "[...] a tipificação das características 
destes elementos, que denominamos conteúdos, é uma construção intelectual para compreender o pensamento e o comportamento das pessoas".

Zabala (1998) organiza uma tipologia de conteúdos de forma a esclarecer critérios que orientem a prática educativa para alcançar determinados fins da educação. Assim, é importante saber o que se ensina e por que motivos. Nesse contexto, Coll e colaboradores (1992) apontam que a falta de ênfase na discussão sobre os conteúdos didáticos está relacionada a uma interpretação de que os processos de ensino e de aprendizagem estariam ligados às atividades de transmissão e acumulação de conhecimentos. Segundo tais autores, com o surgimento de novas estratégias pedagógicas, a rejeição das estratégias tradicionais levou também à desvalorização dos conteúdos e da forma em que eram aprendidos. Subjacente à crítica de Coll e colaboradores (1992), está o problema da própria definição do objeto dos processos de ensino e de aprendizagem; em suma, a questão filosófica de definir o próprio objeto da educação. Sobre a questão do que é e do que não é conteúdo, Zabala e Arnau (2010, p. 20-21), claramente, afirmam que:

[a] pressão do saber teórico acadêmico e das ideias errôneas sobre a aprendizagem e a transferência dos saberes determinaram a preponderância dos conhecimentos factuais e conceituais, tanto é assim que para a maioria dos professores a expressão 'conteúdos de ensino' se limita apenas aos conhecimentos, ou seja, ao saber, dando por certo que os procedimentos, as habilidades, as estratégias, as atitudes e os valores são outra coisa, quer dizer, não são objetos da educação e, portanto, não são conteúdo do ensino.

Em convergência com esta análise, Zabala (1998) aponta uma generalização normalmente aceita de que os conteúdos se referem somente a conceitos, teorias e princípios, restringindo-se a uma dimensão cognitiva do conteúdo de aprendizagem na educação. É comum, de fato, ouvirmos de professores que um determinado currículo ou livro didático é muito "conteudista", sendo que, normalmente, se está compreendendo conteúdo, nestes casos, como sinônimos de conceitos, conhecimentos ou algum objeto similar. Entretanto, no âmbito de uma formação integral do sujeito, as intenções educacionais devem estar para além da aprendizagem de conceitos, teorias e princípios, pois, segundo Zabala (1998) - na medida em que contribui para uma formação mais integral dos estudantes, dando conta de uma diversidade de inteligências, de interesses, potencialidades e necessidades (seja individual ou coletivamente) -, tudo aquilo que desenvolva capacidades motoras, afetivas, de relação interpessoal e de inserção social deve também ser considerado como conteúdo de aprendizagem. Nesse contexto, o autor destaca a importância de se explicitar aprendizagens que geralmente estão implícitas nos currículos e, principalmente, nos planos e nas salas de aula, o que é conhecido por alguns como "currículo oculto" (KENTLY, 2009), as normas, valores e crenças não declarados ou explicitados como parte do currículo, mas que, de fato, são transmitidas aos estudantes através de regras sociais subjacentes ou subliminares às próprias rotinas e modos de organização do 
processo educativo nas salas de aula e nas escolas. (GIROUX, 2001) É necessário desocultar o "currículo oculto" e proceder a este movimento a partir da explicitação detalhada, mas equilibrada, dos conteúdos que se pretende ensinar. Assim, é possível se estabelecer uma relação mais clara e honesta entre três elementos: os próprios conteúdos em suas dimensões, os meios ou métodos para se abordá-los no dia a dia dos processos educativos e a finalidade que se pretende para a educação no todo social.

Assim, para nós, propostas explícitas de desocultação do currículo oculto e, nesta linha, de ampliação da concepção de conteúdos do ensino ou dos objetivos da aprendizagem são muito bem-vindas, uma vez que, para além de formar pessoas de modo mais integral, é preciso abordar, de alguma forma, as dimensões não-conceituais dos problemas socioambientais atuais, os que nos colocam em situação de enorme crise. De fato, diante dos problemas socioambientais atuais e da necessidade de indivíduos comprometidos, responsáveis e capazes de participar ativamente para a redução ou a solução desses problemas, apenas o acúmulo de conhecimentos, seja científicos, tecnológicos ou mesmo filosóficos, não é suficiente. (CONRADO, 2013; HEMPEL, 2014; SAVIN-BADEN; MAJOR, 2004) Ainda, para Villa e Poblete (2007), o aumento do conhecimento científico e das tecnologias tem acompanhado o crescimento das desigualdades sociais em todo o planeta, ao invés de melhorarmos nossas formas de conviver. No contexto da educação científica, Noss (2007) discute as dificuldades de se cumprir uma formação adequada de cidadãos quando se coloca ênfase apenas na aprendizagem de conceitos e procedimentos, negligenciando valores e normas presentes no campo da ciência, quando esta interage com a sociedade.

Além disso, na educação tradicional-tecnicista, não há reconhecimento da complexidade e da multidimensionalidade dos conteúdos e dos objetivos educativos, pois as estratégias e os métodos de ensino não permitem questionar os próprios conhecimentos científico e tecnológico, sua inserção e necessidade na sociedade, assim como interesses e ideologias envolvidos. Por exemplo, ainda há grande necessidade de refletir e discutir mais sobre questões éticas referentes aos processos de produção, uso e descarte de agrotóxicos, sobretudo no caso do Brasil, o maior consumidor mundial de agrotóxicos. (ANDRADE et al., 2016; CARNEIRO et al., 2015; FERNANDES; STUANI, 2015; OLIVEIRA, 2010)

Neste sentido, a educação científica tradicional-tecnicista comete o que podemos chamar de vícios conceitualista e tecnicista, ou seja, concebe o conteúdo de modo unidimensional, priorizando ou mesmo assumindo como as únicas legítimas, respectivamente, a dimensão conceitual e a dimensão procedimental dos conteúdos. Deve-se notar que tal crítica faz sentido à luz de uma concepção mais ampla de conteúdo.

Coll e colaboradores (1992) e Zabala (1998) diferenciam e caracterizam, metodologicamente, com base em processos cognitivos e condutais da aprendizagem, três tipos de conteúdos: conceituais, procedimentais e atitudinais (CPA). Assim, neste trabalho, a definição das dimensões CPA dos conteúdos foi inspirada nas propostas de Coll e cola- 
boradores (1992), Zabala (1998) e Zabala e Arnau (2010), mas também em algumas convergências desses autores com os trabalhos de Clément (2006) e Villa e Poblete (2007).

No âmbito da síntese que propomos, assumimos a terminologia de Coll e colaboradores (1992) e de Zabala (1998) para os elementos constituintes das dimensões CPA dos conteúdos, pois esta nos parece a proposta mais bem elaborada e precisa, tendo, inclusive, influenciado a formulação dos parâmetros curriculares nacionais do Brasil. (BRASIL, 1997) Assim, mostraremos como as dimensões CPA dos conteúdos podem ser utilizadas para a definição dos objetivos de aprendizagem no ambiente escolar ou acadêmico e como podem ser buscados a partir da adoção de propostas de ensino baseadas em QSC. Na Figura 1, pode ser visualizada uma síntese da concepção de Clément com a de Coll e Zabala, a fim de orientar a organização dos objetivos de aprendizagem dos conteúdos.

Figura 1 - Representação das dimensões CPA do conteúdo escolar/acadêmico que podem ser didaticamente separadas em objetivos de aprendizagem

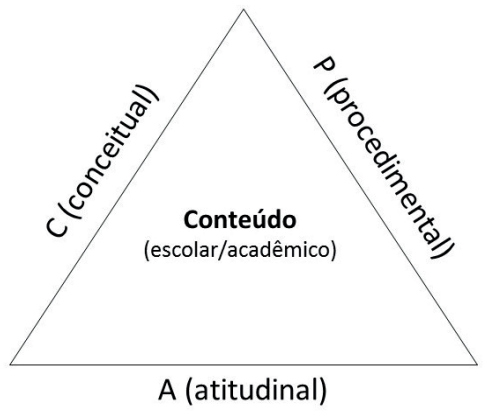

Fonte: elaborada pelos autores com base em Conrado (2017), Coll e colaboradores (1992), Zabala (1998), Clément (2006), Conrado e colaboradores $(2015,2016)$ e Conrado e Nunes-Neto (2015).

Conforme Villa e Poblete (2007), podemos organizar os objetivos de aprendizagem em três categorias de competências:

- instrumentais, que são habilidades motoras e cognitivas que possibilitam o exercício da profissão (por exemplo: capacidades de pensamento lógico, planejamento e comunicação verbal e escrita);

- interpessoais, que estão relacionadas a atitudes para uma boa convivência social (por exemplo: capacidades para trabalho em equipe e automotivação), o que envolve aprendizagem e prática de virtudes, epistêmicas ou morais (como, por exemplo: racionalidade, precisão semântica, honestidade, responsabilidade, autorreflexão, solidariedade, compaixão, empatia); e

- sistêmicas, que podem ser consideradas como aquelas capacidades de compreensão e participação no todo (por exemplo, capacidade de gestão, criatividade e liderança); além do sentido de pertencimento e da ação humana para 
a manutenção de um sistema como um todo (por exemplo, uma cidade, uma sociedade, um ecossistema, um planeta). (MARTÍN, 2006)

Essas três categorias organizadas por Villa e Poblete (2007) podem ser visualizadas em convergência com a tipologia de conteúdos de Coll e colaboradores (1992) e Zabala (1998) na Figura 2. Nessa figura, podemos visualizar que a abordagem das dimensões conceituais e procedimentais do conteúdo, na educação científica tradicional-tecnicista, restringe o foco dos processos educativos ao aprendizado do que Villa e Poblete (2007) chamam de competências instrumentais. Apesar de não considerarmos os conteúdos CPA como tipos de conteúdos, e nem as categorias instrumentais, interpessoais e sistêmicas como competências (que consideramos muito mais como capacidades e habilidades), utilizamos uma síntese das ideias dos autores supracitados, com fim didático, para visualizar os elementos a serem abordados explicitamente como objetivos de aprendizagem na educação científica, para que esta possa contribuir, de fato, para formar indivíduos capazes de tomada de decisão socioambientalmente responsável (CONRADO, 2013, 2017) e ação sociopolítica (HODSON, 2011, 2013; REIS, 2013) sobre problemas socioambientais que envolvem a ciência e a tecnologia.

Figura 2 - Uma síntese das convergências de objetivos de aprendizagem

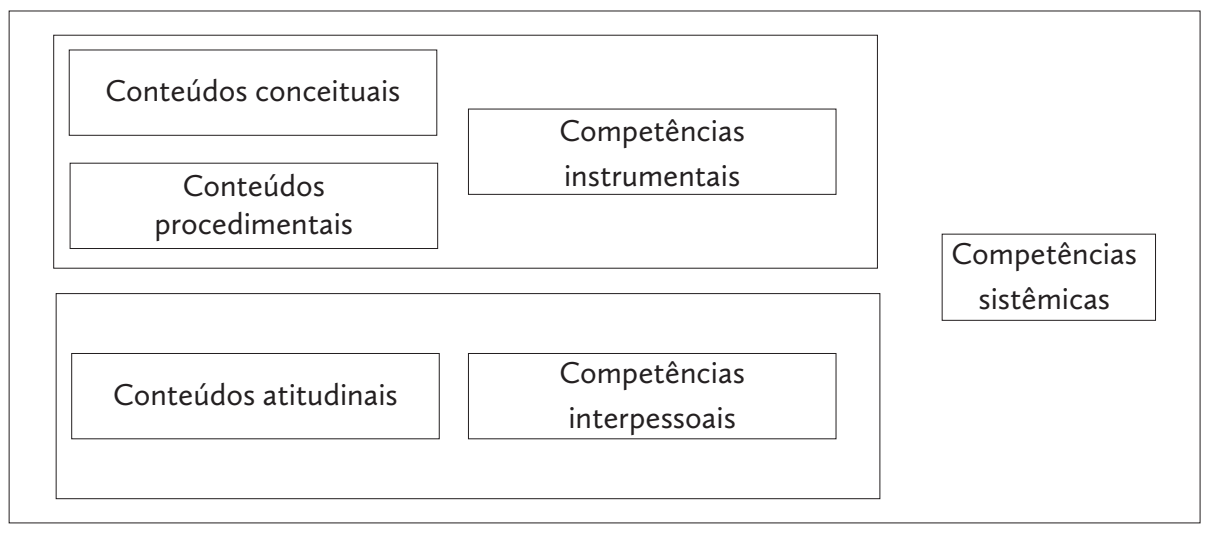

Fonte: adaptada de Conrado (2017), Coll e colaboradores (1992), Zabala (1998) e Villa e Poblete (2007).

Deste modo, para o estabelecimento de objetivos de aprendizagem, em vistas do desenvolvimento de capacidades e habilidades instrumentais, interpessoais e sistêmicas, recomendamos considerar os conteúdos a serem aprendidos em diferentes fases da unidade/intervenção didática.

Assim, em determinados momentos, um conteúdo terá uma dimensão conceitual predominante (por exemplo, em atividades de leitura e de definição de termos), em outros momentos dos processos de ensino e aprendizagem terá destaque a dimensão procedimental (por exemplo, em atividades de investigação, elaboração de argumen- 
tos ou uso de equipamentos) e, por fim, em outros, a dimensão atitudinal será a preponderante (por exemplo, em atividades de discussão de legislação e valores morais, emissão de juízo moral, trabalho colaborativo ou organização de ações sociopolíticas). No Quadro 1, podemos visualizar um exemplo que explicita diferentes dimensões desses conteúdos, em diferentes áreas do conhecimento, considerando uma QSC sobre agrotóxicos.

Quadro 1 - Exemplo de relações entre dimensões dos conteúdos e áreas para uma QSC sobre agrotóxicos

\begin{tabular}{|c|c|c|c|c|}
\hline ÁREA & Conteúdo & $\begin{array}{l}\text { Dimensão } \\
\text { conceitual }\end{array}$ & $\begin{array}{c}\text { Dimensão } \\
\text { procedimental }\end{array}$ & Dimensão atitudinal \\
\hline Ecologia & Biodiversidade & $\begin{array}{l}\text { C: conceito de } \\
\text { biodiversidade }\end{array}$ & $\begin{array}{l}\text { P: medida de } \\
\text { biodiversidade }\end{array}$ & $\begin{array}{l}\text { A: legislação ambiental } \\
\text { sobre conservação da } \\
\text { biodiversidade }\end{array}$ \\
\hline Evolução & $\begin{array}{l}\text { Seleção } \\
\text { Natural }\end{array}$ & $\begin{array}{l}\text { C: teoria de } \\
\text { seleção natural }\end{array}$ & $\begin{array}{l}\text { P: cálculo de } \\
\text { frequência alélica }\end{array}$ & $\begin{array}{l}\text { A: uso adequado de } \\
\text { agrotóxicos, após reflexão } \\
\text { crítica }\end{array}$ \\
\hline Ética & Biocentrismo & $\begin{array}{l}\text { C: definição de } \\
\text { biocentrismo }\end{array}$ & $\begin{array}{l}\text { P: procedimentos } \\
\text { de lógica e } \\
\text { argumentação }\end{array}$ & $\begin{array}{l}\text { A: reflexão, discussão e } \\
\text { ação, segundo ampliação de } \\
\text { consideração moral }\end{array}$ \\
\hline $\begin{array}{l}\text { Fisiologia } \\
\text { humana }\end{array}$ & $\begin{array}{l}\text { Ação dos } \\
\text { agrotóxicos }\end{array}$ & $\begin{array}{l}\text { C: fatos sobre } \\
\text { agrotóxicos no } \\
\text { organismo }\end{array}$ & $\begin{array}{l}\text { P: mensuração } \\
\text { de resíduos de } \\
\text { agrotóxicos }\end{array}$ & $\begin{array}{l}\text { A: discussão sobre valor da } \\
\text { vida e direitos humanos }\end{array}$ \\
\hline Economia & Valor & $\begin{array}{l}\text { C: fatos históricos } \\
\text { sobre transações } \\
\text { comerciais }\end{array}$ & $\begin{array}{l}\text { P: precificação e } \\
\text { codificação }\end{array}$ & $\begin{array}{l}\text { A: valoração dos serviços } \\
\text { ecossistêmicos afetados } \\
\text { pelos agrotóxicos }\end{array}$ \\
\hline
\end{tabular}

Fonte: elaborado pelos autores com base em Conrado (2017).

\section{Dimensão conceitual dos conteúdos ${ }^{1}$}

A dimensão conceitual dos conteúdos refere-se predominantemente a um campo epistemológico e pode ser compreendida, inicialmente, a partir de três categorias: fatos, conceitos e princípios.

Fatos são informações, acontecimentos, dados, eventos ou fenômenos concretos que geralmente são repetidos, de modo a serem memorizados e integrados nas estruturas de conhecimento do estudante. Compreendem os eventos de natureza empírica, como fenômenos particulares, e instanciações de padrões gerais. Não precisam, necessariamente, ser compreendidos, mas é suficiente que sejam memorizados e reprodu-

1 Apesar de adotarmos a mesma terminologia de Zabala (1998) para os elementos constituintes das dimensões dos conteúdos, propomos reinterpretações ou reelaborações dos significados dos termos colocados pelos autores, no sentido de tornar mais precisa a abordagem que considera as dimensões CPA dos conteúdos e ainda mais claramente fundamentada nos seus pressupostos teóricos-filosóficos. 
zidos, por exemplo, a partir de exercícios de repetição. São exemplos de fatos: na anatomia, os nomes de músculos; na evolução, o ano da publicação da obra $A$ origem das espécies; na geologia, a classificação das rochas; e na química, o número atômico do elemento hidrogênio.

Os conceitos se referem, segundo Zabala (1998, p. 42), ao "[...] conjunto de fatos, objetos ou símbolos que têm características comuns [...]”. Contudo, aqui nós consideramos que um conceito deve ser entendido como um termo com seu significado preciso, uma vez que um determinado termo como "banco", pode assumir, a depender dos contextos particulares, diferentes significados (por exemplo, instituição financeira, assento, ou ainda pode ser um verbo). Uma característica importante dos conceitos, que os diferenciam dos fatos, ainda que não dos princípios, é sua generalidade, ou seja, conceitos são entidades teóricas que se referem a um conjunto amplo de eventos, fenômenos ou fatos, ao invés de um particular. Exemplos de conceitos relevantes nas ciências da vida são: biodiversidade (riqueza e abundância de espécies); gene (fragmento funcional do material genético); função (capacidade de uma parte de um sistema que contribui para uma capacidade do sistema que a contém); nicho ecológico (hipervolume n-dimensional que contém condições e recursos que limitam a sobrevivência e a reprodução dos organismos). ${ }^{2}$

Por sua vez, os princípios se referem, conforme Zabala (1998, p. 42), às “[...] mudanças que se produzem num fato, objeto ou situação em relação a outros fatos, objetos ou situações [...]”. Zabala (1998) destaca, em sua definição, o aspecto de mudança, de relação, associado aos princípios, com o que estamos de acordo. Entretanto, mais precisamente, em nossa concepção, adequada para a educação científica, além de tratarem do aspecto da mudança ou da relação, os princípios devem ser compreendidos também com relação aos objetivos da ciência. Assim, eles são elementos teóricos que possibilitam explicações, previsões e descrições de fatos e, como tais, são componentes importantes de teorias, modelos, generalizações ou normas naturais (como as regularidades naturais, em forma de lei). De modo geral, assim, em termos epistemológicos, no que cabe às explicações científicas, eles cumprem o papel de explanans, isto é, a estrutura teórica destinada a explicar certos fatos ou fenômenos, estes últimos, por sua vez, o explanandum. Ainda, os princípios podem ser entendidos como constituintes de representações ou modelos de natureza teórica e como sendo compostos de conceitos e instanciados em fatos. Estes são alguns exemplos de princípios: na biologia, seleção

2 Cabe notar que a própria lista dos conceitos, que compõe uma determinada teoria na ciência, ou, ainda, as definições particulares dos termos dependerão sempre da perspectiva teórica assumida no campo, o que não caracteriza os conceitos como imutáveis e independentes de um contexto sócio-histórico da ciência. Isto é claro, por exemplo, com relação aos termos biodiversidade, gene, função e nicho, mencionados acima. Todos eles dependem de certa perspectiva teórica (como um paradigma, programa de pesquisa ou tradição de pesquisa) construídos num determinado período histórico, por determinados sujeitos e com base em determinados valores, necessidades e interesses. 
natural e exclusão competitiva; na física, a segunda lei da termodinâmica; na química, lei ou princípio da conservação da energia.

Diferentemente dos fatos, os conceitos e princípios são elementos abstratos, que necessitam ser compreendidos (sobretudo quanto a seu significado) e não meramente memorizados pelos estudantes. Da nossa perspectiva, a compreensão ocorre, sobretudo, a partir da mobilização em situações concretas em que eles são necessários, como, por exemplo, no oferecimento de explicações científicas, na articulação entre diferentes fatos, conceitos e princípios; na interpretação de fatos novos; ou até mesmo na elaboração de novos conceitos ou princípios.

A seleção de atividades, em uma intervenção didática com base em QSC, para a aprendizagem da dimensão conceitual dos conteúdos, deve considerar, além da possibilidade de estimular o estudante, a mobilização de fatos, conceitos, princípios em contextos distintos daquele apresentado no tema, ou no caso particular, no qual se expõe a QSC; a conexão com conhecimentos prévios do estudante; e a quantidade de informações possíveis de se abordar no tempo escolar/acadêmico disponível.

Ainda, é relevante levar em conta que, em geral, nos currículos escolares e acadêmicos, a maior parte do conteúdo explícito é composto de fatos, conceitos e princípios, o que reforça o viés conceitualista (como já apontamos acima) e, por isso mesmo, relega a segundo plano as outras dimensões do conteúdo. Na medida em que há excesso da dimensão conceitual dos conteúdos, faz-se necessária uma seleção dos conteúdos no ensino de ciências - a fim de promover uma redução consciente e equilibrada da quantidade de fatos, conceitos e princípios no ensino de ciências (CARVALHO, 2016; CARVALHO; NUNES-NETO; EL-HANI, 2011), tanto para melhor aproveitamento da aprendizagem da própria dimensão conceitual dos conteúdos (uma vez que, supomos, ensinar menor quantidade de fatos, conceitos e princípios pode permitir que ensinemos apenas aqueles que são de fato centrais, estruturantes, aos estudantes), quanto para permitir - a partir desta redução - maior presença explícita das dimensões procedimental e atitudinal dos conteúdos nas aulas de ciências.

Contudo, para que seja possível considerar as dimensões CPA dos conteúdos, no ensino de ciências, é necessário aumentar o uso de técnicas não tradicionais de ensino e reduzir a quantidade de conceitos no currículo e no planejamento didático, de forma a promover uma maior qualidade da aprendizagem e permitir uma educação mais integral dos sujeitos. (CARVALHO; NUNES-NETO; EL-HANI, 2011) Este é um desafio importante para o ensino de ciências atualmente.

\section{Dimensão procedimental dos conteúdos}

A dimensão procedimental dos conteúdos refere-se predominantemente a um campo metodológico e pode ser compreendida, inicialmente, a partir de três categorias: técnicas, procedimentos e métodos. De um modo geral, Coll e colaboradores (1992, p. 101) definem os conteúdos procedimentais como "[...] conjuntos de ações, de formas de atuar e 
de chegar a resolver tarefas [...] solucionar problemas, para chegar a objetivos ou metas, para satisfazer propósitos e para conseguir novos aprendizados".

Procedimentos representam ações (cognitivas e motoras) ordenadas, para se alcançar um fim determinado, com base em técnicas e métodos consensualmente aceitos. (ZABALA, 1998) Exemplos de procedimentos são: elaboração de um argumento; construção de um gráfico; ou, ainda, confecção de uma maquete.

Técnicas são as atividades necessárias para se realizar um procedimento. São exemplos de técnicas: resenha de uma obra, a partir do destaque de pontos principais; análise um argumento, por meio de sua estrutura; seleção de materiais, conforme palavras-chave do assunto; realização de medidas com régua; classificação de elementos em um conjunto com base em algum critério.

Métodos, em nossa perspectiva, representam uma perspectiva mais geral de uma ação, que envolve técnicas e procedimentos variados, em categorias específicas de acordo com seus objetivos. De um modo geral, nos parece adequado organizar hierarquicamente estes elementos: os métodos podem ser compostos por procedimentos e estes podem ser compostos por técnicas. Exemplos de métodos são: descrição; comparação; explicação; experimentação.

Os conteúdos, quando abordados nessa dimensão mais metodológica, são melhor compreendidos quando ocorre uma exemplificação prévia à realização da tarefa, além de ser necessário que essas ações sejam repetidas, exercitadas, em diferentes contextos, e consideradas também a partir da reflexão sobre sua prática. Nesse sentido, as atividades relacionadas aos conteúdos procedimentais devem partir de situações significativas para que o estudante perceba claramente a função e a importância do procedimento, do método ou da técnica. Por isso, e particularmente em relação à resolução de QSC, recomenda-se, na intervenção didática, haver momentos de "modelagem" (HODSON, 2011), de modo a explicar os diferentes procedimentos, assim como momentos de auxílio orientado - similar à fase de prática guiada, de Hodson (2011) -, de modo a acompanhar o desempenho do estudante na execução e no domínio das tarefas relacionadas ao conteúdo. Por exemplo, se um objetivo de aprendizagem for o desenvolvimento de habilidades argumentativas, é importante que os procedimentos, os critérios e as técnicas para um bom argumento sejam ensinados e demonstrados, para depois serem praticados e avaliados em termos da aprendizagem do estudante. Contudo, algumas tarefas podem ter como objetivo de aprendizagem a própria elaboração do procedimento (COLL et al., 1992), a partir dos conhecimentos e capacidades prévios dos estudantes. Nesse caso, o estudante precisará construir, pouco a pouco, o caminho metodológico, selecionando técnicas e métodos para se alcançar a meta estabelecida. Então, nestes casos, o conteúdo a ser aprendido não se limitaria ao conhecimento e à execução de uma sequência de passos, mas à criação destes para alcançar um resultado geral ou específico associado à resolução do problema. 
Coll e colaboradores (1992) observam que os procedimentos, técnicas e métodos possuem graus de automatização. Isso significa que o estudante, inicialmente, ao aprender sobre essa dimensão do conteúdo, poderá apresentar dificuldades iniciais e executar as atividades desde um modo mais rudimentar até uma maneira mais precisa e automática. Por exemplo, a aprendizagem sobre o procedimento de manipulação do microscópio, que demanda o domínio de técnicas manuais, pode ser inicialmente difícil para um estudante de biologia, ou trivial para um estudante de pós-graduação da área, que lida diariamente com esse aparelho em suas atividades de pesquisa. Além disso, o domínio de um procedimento, uma técnica ou um método pode ocorrer para diferentes contextos, como, por exemplo, o uso adequado do microscópio para observar lâminas de diferentes materiais. Considerando que há níveis de dificuldade, complexidade, aplicação e tempo para a realização de tarefas, podemos organizar tabelas para avaliar o progresso do estudante com base nesses critérios. (VILLA; POBLETE, 2007; ZABALA, 1998)

Ainda nesse contexto, também esclarecemos que a dimensão procedimental do conteúdo deve ser compreendida, como Zabala (1998) propõe, em um eixo cognitivo-motor (de ação técnica). Desse modo, a execução dos procedimentos, técnicas e métodos será por ora mais cognitiva e linguística (como, por exemplo, uma explicação de um fenômeno) e por outras vezes mais motora (como, por exemplo, uma experimentação ou manipulação de reagentes em laboratório).

Por fim, Coll e colaboradores (1992) alertam os professores para que saibam distinguir entre, de um lado, os procedimentos, técnicas e métodos como objetivos de aprendizagem para os estudantes e, de outro, os recursos, métodos e estratégias para os professores, como veículos da prática pedagógica em sala de aula, ou seja, o recurso ou o método adotado para o ensino e a aprendizagem (esperada) nem sempre é equivalente ao procedimento ou ao método que o estudante precisa aprender. Por exemplo, o uso de textos de divulgação pode ser um recurso didático adotado pelo docente para facilitar a aprendizagem de determinados conceitos, enquanto a elaboração de um texto de divulgação para a aprendizagem de procedimentos pode ser um objetivo de aprendizagem estabelecido para o estudante.

\section{Dimensão atitudinal dos conteúdos}

A dimensão atitudinal dos conteúdos refere-se predominantemente a um campo axiológico; e, neste âmbito, do nosso ponto de vista, principalmente, ético-político. Assim, ela pode ser compreendida, inicialmente, a partir de três categorias: valores, normas e atitudes.

Os valores são parâmetros ou critérios para juízo moral sobre condutas com base na ética. As normas são padrões ou regras de comportamento estabelecidos e compactuados para um grupo ou coletividade. As atitudes são tendências ou predisposições de conduta dos sujeitos com base em normas e valores. (VILLA; POBLETE, 2007; ZABALA, 1998) Esses elementos dos conteúdos precisam ser vivenciados em situações concretas 
e simuladas para que se exercite e se reflita sobre as próprias ações e as de outros atores sociais.

Para Zabala (1998), o valor é aprendido quando, além da compreensão sobre o conceito do valor, são relacionados e assumidos critérios morais para seu juízo. Assim, esses critérios morais permitirão a avaliação da própria atuação do sujeito e das ações de outros. Todos os valores que consideramos nesta dimensão atitudinal são fundamentados na ética e, por conseguinte, são condições para as ações em que cabem juízo moral. Neste sentido, da perspectiva ético-política que caracteriza a dimensão atitudinal, as ações são examinadas e devem ser realizadas de um ponto de vista normativo ético-político, não apenas técnico. Para nós, aqui está uma diferença relevante entre as ações vistas de uma perspectiva ético-política (isto é, desde uma dimensão atitudinal) e as ações técnicas ou procedimentos (dimensão procedimental).

Conforme Zabala (1998, p. 47), aprende-se uma atitude “[...] quando a pessoa pensa, sente e atua de uma forma mais ou menos constante frente ao objeto concreto a quem dirige essa atitude”. Quanto às normas, para Zabala (1998, p. 47):

Podemos dizer que se aprendeu uma norma em diferentes graus: num primeiro grau, quando se trata de uma simples aceitação, embora não se entenda a necessidade de cumpri-la (além da necessidade de evitar uma sanção); em segundo grau, quando existe uma conformidade que implica certa reflexão sobre o que significa a norma e que pode ser voluntária ou forçada; e em último grau, quando se interiorizaram as normas e se aceitam como regras básicas de funcionamento da coletividade que regem.

Elaborando sobre isso, podemos dizer que quanto maior a reflexão sobre as razões que justificam a ação, o conhecimento sobre normas e a consciência sobre valores morais relacionadas às atitudes, menor a ocorrência de disposições intuitivas e, assim, podemos dizer, maior a reflexividade crítica sobre as ações. Esta maior reflexividade crítica sobre os elementos constituintes da dimensão atitudinal dos conteúdos relaciona-se positivamente com o grau de autonomia do estudante, de nossa perspectiva.

De modo geral, para ocorrer aprendizagem da dimensão atitudinal dos conteúdos, é necessário, além de conhecer, refletir, analisar e avaliar as normas e os valores envolvidos na situação-problema, "[...] uma tomada de posição, um envolvimento afetivo e uma revisão e avaliação da própria atuação”. (ZABALA, 1998, p. 48) Nesse sentido, a aprendizagem de valores, normas e atitudes é, via de regra, a mais complexa, pois:

- envolve, em maior grau, elementos de afetividade e interesse;

- influencia a compreensão e a reflexão sobre as dimensões conceituais e procedimentais relacionadas ao conteúdo; e, ainda,

- $\quad$ abrange a rede de relações estabelecidas no ambiente educativo. 
Devido a essas características, é importante considerar a dinâmica das relações entre a comunidade escolar, envolvendo ativamente os estudantes e professores em processos de sensibilização e de participação quanto às normas e aos valores promovidos na unidade educativa, seja a sala de aula, seja a escola, seja uma comunidade de aprendizagem mais abrangente. Apesar da importância de se abordar explicitamente valores, normas e atitudes em sala de aula, a seleção dos objetivos de aprendizagem relacionados a essa dimensão deve ocorrer de acordo com as necessidades, os interesses, os conteúdos prévios e os contextos sociais envolvidos.

\section{Valores, normas e atitudes no ensino de ciências}

A educação científica, quando privilegia apenas a aprendizagem das dimensões conceituais e procedimentais dos conteúdos científicos, está contribuindo para a formação de cidadãos acríticos em relação às influências mútuas entre ciência, tecnologia, sociedade e ambiente (VON LINSINGEN; CASSIANI, 2010), pois desprivilegia ou negligencia dimensões éticas que inevitavelmente estarão presentes tanto na atividade científica quanto nas escolhas e ações cotidianas dos cidadãos. (FOUREZ, 1995, 2008) Não estamos dizendo, é importante destacar, que na abordagem didática de alguns casos estariam presentes apenas as dimensões conceitual e procedimental dos conteúdos e, assim, estariam simplesmente ausentes elementos de dimensão atitudinal dos conteúdos. Todos os conteúdos possuem, de nossa perspectiva, as três dimensões invariavelmente; o que variará entre os conteúdos será a predominância ou a explicitude de uma dimensão sobre as outras. Deste modo, o problema é, precisamente, a falta de explicitação, nos processos de ensino e aprendizagem, dos elementos dos conteúdos ("sobre" e "de" valores, normas e atitudes), em suas qualidades e quantidades, que estão e sempre estarão, de fato, presentes.

Muitos trabalhos têm ressaltado a importância de serem explicitados os valores associados à ciência e à tecnologia, indicando a relevância da dimensão atitudinal do conteúdo - ou algo similar - no ensino de ciências (GOERGEN, 2007; HODSON, 2004; SADLER, 2004a; SANTOS, 2012; ZEIDLER et al., 2005), sobretudo para: dar conta da diversidade de interesses e capacidades dos estudantes, que não podem ser reduzidos a uma dimensão puramente conceitual e/ou procedimental (ZABALA, 1998); uma melhor compreensão da atividade científica (LACEY, 2010); a mobilização de conteúdos científicos no cotidiano (CONRADO, 2013); o reconhecimento da influência de valores no desenvolvimento científico e tecnológico (SADLER, 2004a); a percepção de pertencimento a uma comunidade e responsabilidade em relação aos problemas socioambientais que afetam esta comunidade, por exemplo. (MARTíN, 2006)

No âmbito do trabalho com QSC, devemos considerar os conflitos e as controvérsias como oportunidades de promover o debate e a reflexão crítica sobre valores, normas, atitudes, pontos de vista e tomadas de decisão distintos. Mas como tais elementos do conteúdo CPA podem ser abordados no ensino? 
O uso de casos - como temos defendido - nos permite observar possíveis tomadas de decisão, que envolverão os elementos da dimensão atitudinal, por exemplo, vejamos um caso que pode ser aplicado no âmbito de uma proposta de ensino curta, para ensino médio ou ensino superior. Trata-se do caso de Beckert (2004), sobre a descoberta de uma embarcação antiga naufragada com obras de arte intactas. É solicitado aos estudantes que optem pela: recuperação de artefatos culturais antigos, com impactos no ecossistema natural; ou recuperação de artefatos culturais antigos, com o uso de tecnologias que permitem a conservação de golfinhos que habitam o local; ou, por fim, pela não recuperação dos artefatos e preservação da integridade e da estabilidade do ecossistema local. Na discussão sobre razões que influenciam a tomada de decisão, além dos conhecimentos científicos e tecnológicos, elementos de ética poderão ser colocados pelo professor, como: as teorias éticas que fundamentam a justificativa para a decisão tomada (RACHELS, 2006; SINGER, 2011); e a ontologia moral para a consideração moral dos envolvidos. (FELIPE, 2009; SINGER, 2011) Consideremos, em separado, a seguir, as teorias éticas e a ontologia moral.

Apenas com fim didático e de modo muito simplificado, podemos dizer que as principais teorias éticas da filosofia moral ocidental são três: a ética das virtudes, o utilitarismo (principal corrente do consequencialismo) e a deontologia ou ética Kantiana. (BONJOUR; BAKER, 2010; SINGER, 2011; WARBURTON, 2007)

A ética das virtudes, que, no Ocidente, surge com Aristóteles, apela às virtudes necessárias aos sujeitos para uma boa conduta, mas, sobretudo, para uma boa vida. Da perspectiva das virtudes, importa muito o encaixe de cada agente humano no todo social, no cosmos, poderíamos dizer. Por esta razão, esta é uma ética funcionalista, acerca da função, do papel que cada um cumpre no todo, o que está em pleno acordo com a metafísica e a epistemologia de Aristóteles. De acordo com a ética das virtudes, desde que voltada às ações individuais como seu objeto, a pergunta "o que devo fazer?" deve ser respondida apelando àquilo que um agente considerado virtuoso faria. (BECKERT, 2012; BONJOUR; BAKER, 2010; HURTSHOUSE, 2013)

Por sua vez, a ética consequencialista - cujos principais representantes foram J. Bentham e J. S. Mill, nos séculos XVIII e XIX, proponentes do utilitarismo - defende que uma ação é boa quando ela tem uma consequência boa. Da perspectiva consequencialista utilitarista, em particular, importa que a ação tenha consequências que maximizem o bem (medido em termos de prazer ou evitando a dor, por exemplo), para o máximo possível de envolvidos. (BONJOUR; BAKER, 2010; SINGER, 2004)

Por fim, a ética deontológica, cujo representante máximo na modernidade foi Kant, também nos séculos XVIII e XIX, está baseada numa análise da própria ação, não das suas consequências, como critério para justificá-la; nem tampouco nas virtudes dos agentes. Kant baseava o julgamento das ações humanas no imperativo categórico, que já foi formulado de diferentes maneiras, uma delas sendo que cada um de nós deve agir 
de acordo com a máxima de tratar cada ser humano como um fim em si mesmo, não

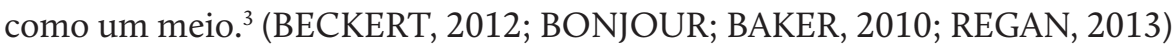

Didaticamente, nos parece importante destacar, como ponto central da discussão sobre as teorias éticas, o foco sobre o critério para atribuição de valor à ação. Enquanto o critério, para o defensor da ética das virtudes, é o que um agente virtuoso faria, para o utilitarista seria buscar a consequência da ação que maximiza o bem do máximo de envolvidos, e para o deontológico, não se basear nas consequências possíveis, nem nas virtudes, mas sim seguir um princípio que se alinhe ao imperativo categórico. É importante perceber que enquanto teorias que oferecem critérios para atribuir valor à ação humana, tais teorias não se referem explicitamente ao alcance da consideração moral, isto é, a "quais" ou "quem" devem ser aqueles considerados pela ação, quando do julgamento ou da atribuição de valor sobre ela. Em outras palavras, as teorias morais não explicitam, por si mesmas, os envolvidos, isto é, os seres com os quais devemos nos preocupar quando formulamos juízos éticos sobre o valor das nossas ações e quando agimos.

A fim de contemplar quais ou quem devem ser aqueles considerados pela ação, portanto quem tem valor, devemos focalizar o campo da ontologia moral. Aqui, podemos distinguir entre três grandes tendências: antropocentrismo, biocentrismo e ecocentrismo. (FELIPE, 2009; SILVA, 2009; VAZ; DELFINO, 2010)

A perspectiva antropocêntrica assume que somente os seres humanos merecem consideração moral e somente ações que afetam os humanos merecem um exame moral. Desse modo, e sob essa perspectiva, por exemplo, os benefícios que os humanos adquirem através dos ecossistemas possuem relevância quando promovem o bem-estar dos seres humanos. De acordo com Bryan Norton (2003), dois tipos de antropocentrismo podem existir neste contexto: um fraco e um forte. $\mathrm{O}$ antropocentrismo forte considera que o valor atribuído a algo é determinado e explicado pela referência à satisfação de preferências sentidas (qualquer desejo que possa ser saciado, pelo menos temporariamente) dos humanos. Por outro lado, o antropocentrismo fraco, apesar de considerar algumas preferências sentidas, reconhece que estas podem estar ou não de acordo com uma visão de mundo racional, permitindo, dessa forma, o estabelecimento de críticas a sistemas de valores que objetivam a exploração da natureza. Ao passo em que rejeita o antropocentrismo forte, Norton (2003) argumenta que o antropocentrismo fraco auxilia na promoção de ideais de comportamento humano que exaltam a harmonia com a natureza e também projeta a natureza como um agente que inspira e influencia a formação de valores dos indivíduos humanos através do contato direto desses indivíduos com a natureza não perturbada.

A perspectiva biocêntrica, por sua vez, caracteriza-se por propor a consideração moral de organismos individuais humanos e não-humanos. Esses organismos vivos pos-

3 Cabe notar que o imperativo categórico pode ser reinterpretado, como, de fato, o foi para incluir também outros seres, não-humanos. (REGAN, 2013) 
suem a mesma relevância (valor) que os seres humanos e, por isso, o desenvolvimento e o bem-estar de todos os seres vivos são valiosos e devem ser respeitados, ou seja, os seres humanos possuem uma obrigação moral para com os outros seres vivos. O biocentrismo pode ser considerado uma ampliação da ética animal, uma vez que ele considera que não apenas os animais (ou alguns deles) têm um valor próprio, mas as plantas também, assim como qualquer outro ser vivo que possui interesses de bem-estar e desenvolvimento; logo, também devem ser considerados como pacientes morais, pelos agentes morais. (BECKERT, 2004; VAZ; DELFINO, 2010) A fim de ilustrar a perspectiva biocêntrica e a ética animal, consideremos, brevemente, a posição elaborada por Tom Regan. Regan (2013) é um reconhecido teórico defensor da ideia dos direitos dos animais, segundo a qual os animais, assim como os humanos, são sujeitos-de-uma-vida (e não vidas sem sujeitos), por também apresentarem, de forma autônoma, desejos, sensações de prazer e sofrimento; logo, também possuem valor inerente como os humanos e, por isso, devem ser tratados com respeito. Em outras palavras, os humanos possuem deveres diretos em relação aos animais, e não apenas deveres indiretos, como argumentam defensores da perspectiva antropocêntrica, no âmbito da ética animal. Ainda, como tem sido extensivamente documentado na literatura desde os anos 1970, Regan (2013) afirma que os direitos dos animais têm sido violados sistematicamente, devido à prevalência de um sistema que permite que os animais sejam vistos como seres desprovidos de valor inerente e explorados como recursos renováveis a serviço dos interesses humanos. Portanto, medidas para redução do sofrimento dos animais na pecuária ou na ciência - ainda que possam ser benéficas no curto prazo - não resolvem o problema, de acordo com Regan (2013). De sua perspectiva, somente a abolição total do uso de animais na ciência, a dissolução total da pecuária comercial, a eliminação total da caça comercial e esportiva e do aprisionamento corrigirão o erro do tratamento dado aos animais não-humanos. Regan (2013) também critica a posição defendida por Peter Singer (2010) para fundamentar a defesa dos animais como objetos de consideração moral, pois, segundo Regan, apesar de não permitir nenhum tipo de discriminação e considerar os interesses de todos com igual relevância (no caso de Singer, com base no critério da senciência), reconhece como importante a satisfação dos interesses do indivíduo, e não o valor do sujeito em si. $^{4}$

A perspectiva ecocêntrica, por sua vez, nos orienta para expandir a consideração moral a entidades ambientais coletivas, inclusive a elementos abióticos, espécies e ecossistemas. Uma implicação dessa perspectiva é a defesa de que sejam considerados moralmente reprováveis quaisquer atos humanos que possam interferir na integridade e

4 Além disso, Regan (2013) critica a característica agregadora do utilitarismo, presente no pensamento de Singer, que nos ordena totalizar ou somar as frustrações e satisfações de diferentes indivíduos a fim de poder tomar a melhor decisão que represente um equilíbrio entre as satisfações e frustrações totalizadas. Entretanto, a melhor decisão não necessariamente representa as melhores consequências para cada indivíduo, o que se coloca como um argumento contrário à perspectiva utilitarista senciocêntrica, de Singer. 
estabilidade dos ecossistemas, pois a realização ou manutenção do bem-estar dessas entidades ambientais coletivas possui relevância; em outras palavras, elas possuem um bem ou valor intrínseco. Aldo Leopold (2003), representante bem conhecido dessa corrente ética, argumenta que, na perspectiva da ética da terra (terra, aqui, sendo compreendida não como planeta, mas com um sentido aproximado de "território"), os seres humanos são considerados simples membros e cidadãos da comunidade da terra que deveriam respeitar tanto os membros companheiros quanto a comunidade como tal. Ainda de acordo com essa perspectiva, as entidades naturais e as comunidades bióticas devem ter asseguradas as condições para sua existência continuada. Logo, da perspectiva de Leopold, uma ação é correta quando tende a preservar a integridade, estabilidade e beleza da comunidade biótica; e é errada quando não o faz.

Em relação ao caso colocado acima, pode-se adotar diferentes posições com relação às justificações para atribuição do valor à ação e também com relação ao escopo da consideração moral. Por exemplo, com relação às teorias éticas, os estudantes podem assumir uma perspectiva consequencialista individualista (quando, por exemplo, a prioridade é o lucro individual), utilitarista (quando, por exemplo, deve haver a concordância sobre uma ação que beneficie o máximo possível de envolvidos) ou deontológica (quando, por exemplo, o princípio da não maleficência, associado a alguma interpretação do imperativo categórico, orienta as ações) ou, ainda, de ética das virtudes (quando, por exemplo, a virtude da não-violência [ahimsa] é prioridade para a ação). Por sua vez, eles podem assumir diferentes perspectivas quanto ao alcance da consideração moral: antropocêntrica (quando tendem a priorizar as preferências exclusivamente humanas, associadas às obras de arte), biocêntrica (quando tendem a priorizar os organismos vivos, sobretudo aqueles capazes de sentir dor, como, por exemplo, os golfinhos; é interessante notar que esta perspectiva também inclui os humanos) e ecocêntrica (quando tendem a priorizar o ecossistema como totalidade, o que permite incluir as algas, o leito oceânico etc.).

A fim de discutir estas possibilidades de posicionamentos, cabem algumas questões norteadoras, a serem colocadas pelo professor no âmbito de uma sequência didática, como:

- Que decisão você tomaria com relação ao caso? Por quê?

- Com base em seus conhecimentos de ética, que teoria ética (consequencialismo individualista, utilitarismo, deontologia ou ética das virtudes) justificaria a sua tomada de decisão com relação ao caso? Explique.

- Quais ou quem são os envolvidos no caso? Que perspectiva sobre o alcance da consideração moral (antropocentrismo, biocentrismo, ecocentrismo) você adotaria?

- Você acredita ser possível conciliar interesses da natureza não-humana (golfinhos, algas, ecossistemas etc.) com interesses humanos (direitos sociais, acesso à cultura etc.)? Justifique. 
A partir da colocação, pelo professor, das questões norteadoras para abordar o caso, podem ser explicitados os objetivos de aprendizagem em termos das dimensões CPA. No caso apresentado por Beckert (2004), podemos fixar, por exemplo, como objetivos de aprendizagem, as dimensões CPA do conteúdo "relações entre humanos e a natureza não-humana", mais comumente conhecida como "relações homem-natureza":

- Conceituais:

- memorizar fatos acerca da história da arte, dos naufrágios, do uso de recursos naturais por seres humanos; compreender os conceitos e princípios associados à ciência, como senciência, autonomia biológica, organismos, interações ecológicas, ecossistemas e fluxo de matéria e energia; além daqueles conceitos e princípios associados à ética, como valor instrumental e valor intrínseco; virtudes, consequencialismo individualista, consequencialismo utilitarista e deontologia; antropocentrismo, biocentrismo e ecocentrismo.

- Procedimentais:

- praticar técnicas, procedimentos e métodos relacionados a: levantamento e organização de informações bibliográficas em bases de dados acadêmicas, a fim de obter textos sobre o assunto; construção de textos dissertativos com clara exposição de ideias e argumentos; uso adequado dos procedimentos de citação e referenciação ao longo dos textos produzidos; análise e construção de argumentos sobre o caso, seja examinando-o, seja visando a elaboração de uma solução para ele; ou ainda, se os ambientes permitirem, prática de procedimentos técnicos, laboratoriais ou de campo, associados ao caso, que envolveria procedimentos, técnicas e métodos de biologia marinha, por exemplo.

- Atitudinais:

- mobilizar e aplicar de forma crítica valores, atitudes e normas, em suas dimensões ético-políticas explícitas, relacionados à consideração moral de humanos e não-humanos, aos critérios para atribuição de valor moral às ações humanas, de acordo com teorias éticas; ser capaz de considerar criticamente e profundamente os diversos valores e interesses sustentados pelos seres humanos nas suas relações com outros seres humanos e com a natureza não-humana, além de repensar e, se necessário, modificar seus próprios valores e ações.

Em suma, este é um breve exemplo do modelo de propostas de ensino com três elementos (caso, questões norteadoras e objetivos CPA de aprendizagem), que pode ser utilizado para a aplicação das QSC no contexto da educação CTSA, sob certas vertentes, em sala de aula. Para um diagrama, ver Figura 3 que representa graficamente esta abordagem. 
Figura 3 - Estrutura de três elementos (caso, questões norteadoras e objetivos CPA de aprendizagem) para abordagem de QSC em sala de aula, a partir do contexto pedagógico da educação CTSA

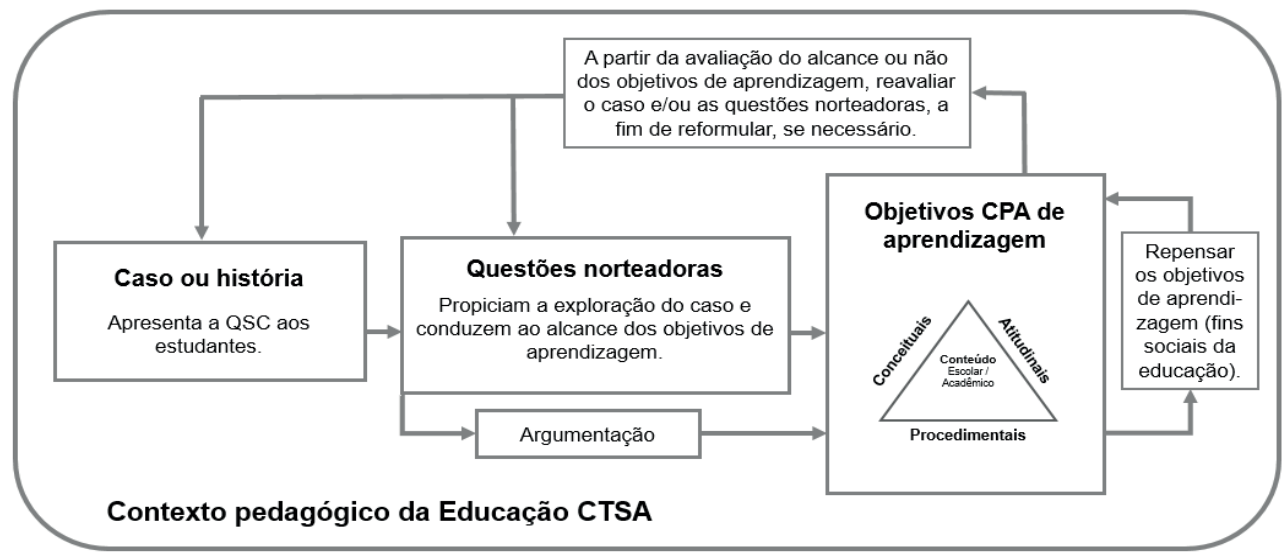

Fonte: elaborada pelos autores com base em Conrado (2017).

Propomos que as análises do papel da ética no ensino de ciências devem estar articuladas, do nosso ponto de vista, com o fomento do raciocínio lógico e do pensamento crítico. Em especial, com relação ao pensamento crítico, Villa e Poblete (2007, p. 76) afirmam que:

El pensamiento crítico va más allá de las destrezas del análisis lógico ya que, como señala Brookfield (1987), implica poner en cuestión los supuestos subyacentes en nuestras formas habituales de pensar y actuar $\mathrm{y}$, en base a ese cuestionamiento crítico, estar preparado para pensar y hacer de forma diferente. Para Moya (2005) el pensamiento crítico es el pensamiento de los interrogantes: ¿por qué las cosas son así?, ¿por qué las cosas no pueden ser de otro modo?, ¿por qué tú crees que las cosas son así?, ¿por qué alguien puede querer que las cosas sean así? [...] En consecuencia, diremos que una persona ha desarrollado la competencia de pensamiento crítico en la medida en que se interroga sobre las cosas y se interesa por los fundamentos en los que se asientan las ideas, las acciones, las valoraciones y juicios tanto propios como ajenos.

Por fim, em relação a um posicionamento neutro ou a uma não tomada de decisão sobre uma QSC, Hodson $(2011,2013)$ advoga o termo “imparcialidade comprometida”, que significa assumir uma posição, mas também não deixar de considerar mais possibilidades e promover a discussão. Deste modo, o professor pode, por um lado, posicionar-se e se comprometer, mostrando a importância de assumir posicionamentos em questões controversas, porém, de outro lado, sem impor sua posição aos estudantes, indicando as possibilidades da forma mais equilibrada possível; além de considerar argumentos e tolerar outros pontos de vista, numa discussão crítica, com atitudes relacionadas à empatia e à não-violência. (COLUCCI-GRAY et al., 2006) 
Uma questão fundamental e constantemente colocada é aquela sobre a avaliação da aprendizagem sobre valores, normas e atitudes. Para a avaliação do alcance da dimensão atitudinal dos conteúdos pelos estudantes, ou seja, do progresso dos estudantes quanto à aprendizagem de valores, normas e atitudes, Villa e Poblete (2007) e Coll e colaboradores (1992) organizam e recomendam indicadores, escalas de atitudes e níveis de progresso.

Para a avaliação do alcance das dimensões CPA dos conteúdos pelos estudantes, incluindo, obviamente, a dimensão atitudinal, e, ainda, com base nos quatro níveis de sofisticação do currículo, de Hodson $(2004,2011),{ }^{5}$ recomendamos ter como base a proposta de Conrado, Nunes-Neto e El-Hani (2016) de uma ferramenta para a análise do alcance de objetivos de aprendizagem pelo estudante durante a resolução de uma QSC (Quadro 2). A proposta consiste em adotar, para cada nível de sofisticação, quatro estágios de aprendizagem crescentes.

Quadro 2 - Instrumento para avaliação dos estágios de letramento científico crítico ${ }^{6}$

\begin{tabular}{|c|c|c|c|c|}
\hline Nível & Estágio o & Estágio 1 & Estágio 2 & Estágio 3 \\
\hline $\begin{array}{l}\text { 1. Reconhecimento } \\
\text { de relações CTSA }\end{array}$ & $\begin{array}{l}\text { Não percebe } \\
\text { conexões e } \\
\text { compartimentaliza } \\
\text { questões e } \\
\text { conhecimentos } \\
\text { entre C, T, S, A na } \\
\text { QSC }\end{array}$ & $\begin{array}{l}\text { Indica benefícios } \\
\text { da ciência e } \\
\text { da tecnologia } \\
\text { sobre sociedade } \\
\text { e ambiente } \\
\text { (perspectiva } \\
\text { salvacionista) }\end{array}$ & \begin{tabular}{|l} 
Aponta \\
demandas da \\
sociedade sobre \\
a ciência e a \\
tecnologia ou \\
impactos da \\
ciência e da \\
tecnologia sobre \\
a sociedade e o \\
ambiente
\end{tabular} & $\begin{array}{l}\text { Reconhece que ciência e } \\
\text { tecnologia são, em certa } \\
\text { medida, culturalmente } \\
\text { determinadas, indicando } \\
\text { relações mútuas entre } \\
\text { conhecimentos de C, T, S, A }\end{array}$ \\
\hline $\begin{array}{l}\text { 2. Reconhecimento } \\
\text { da influência } \\
\text { de interesses } \\
\text { e do poder no } \\
\text { desenvolvimento } \\
\text { científico e } \\
\text { tecnológico }\end{array}$ & $\begin{array}{l}\text { Assume } \\
\text { neutralidade } \\
\text { da ciência e da } \\
\text { tecnologia ou não } \\
\text { explicita valores } \\
\text { e interesses } \\
\text { envolvidos na } \\
\text { atividade científica } \\
\text { e tecnológica }\end{array}$ & \begin{tabular}{|l} 
Indica a \\
influência de \\
interesses de \\
determinados \\
grupos sociais no \\
desenvolvimento \\
científico e \\
tecnológico
\end{tabular} & \begin{tabular}{|l} 
Explicita que a \\
influência do \\
poder, na ciência \\
e na tecnologia, \\
pode gerar \\
consequências \\
negativas para \\
indivíduos, \\
sociedades e \\
ambientes
\end{tabular} & $\begin{array}{l}\text { Reconhece que as atividades } \\
\text { científica e tecnológica } \\
\text { ocorrem sob interesses de } \\
\text { particulares para benefícios } \\
\text { de alguns, às custas de outros, } \\
\text { encontrando exemplos na QSC }\end{array}$ \\
\hline
\end{tabular}

5 Para mais detalhes acerca dos quatro estágios de sofisticação do currículo para ações sociopolíticas relacionadas com a sustentabilidade ambiental, ver Hodson (2011) e Conrado e colaboradores. (2016).

6 Entendemos letramento científico crítico com base em Hodson (2011) e Zeidler e colaboradores (2005). Para nós, um estudante é letrado cientificamente, de um ponto de vista crítico, quando a sua aprendizagem das dimensões CPA dos conteúdos the permite o domínio de habilidades para utilizar adequadamente a linguagem científica (a partir da sua apropriação de modos de falar e argumentar em ciências), maior autonomia (com relação à adaptação de suas decisões com relação às condições naturais ou sociais do entorno), tomar decisões socioambientalmente responsáveis sobre QSC (considerando adequadamente as suas dimensões ético-políticas) e, por fim, executar ações sociopolíticas com relação às QSC, em direção a maiores justiça social e sustentabilidade ambiental. Para mais detalhes, ver Ferreira e colaboradores. (2016), Conrado (2017) e Conrado e colaboradores. (2016). 


\begin{tabular}{|l|l|l|l|l|}
\hline Nível & Estágio o & Estágio 1 & Estágio 2 & Estágio 3 \\
\hline $\begin{array}{l}\text { 3. Capacidade } \\
\text { para abordar } \\
\text { criticamente } \\
\text { controvérsias, para } \\
\text { explicitar valores } \\
\text { e para emitir juízo } \\
\text { ético }\end{array}$ & $\begin{array}{l}\text { Não aponta } \\
\text { controvérsias e } \\
\text { valores distintos } \\
\text { envolvidos nas } \\
\text { relações entre } \\
\text { CTSA e na QSC }\end{array}$ & $\begin{array}{l}\text { Menciona a } \\
\text { presença de } \\
\text { diferentes } \\
\text { valores e } \\
\text { pontos de vista } \\
\text { envolvidos na } \\
\text { QSC }\end{array}$ & $\begin{array}{l}\text { Questiona } \\
\text { juízos, valores e } \\
\text { decisões próprias } \\
\text { e dos outros }\end{array}$ & $\begin{array}{l}\text { Analisa criticamente } \\
\text { contradições e coerência } \\
\text { entre valores e condutas para } \\
\text { formular sua própria opinião } \\
\text { e juízo moral, justificados de } \\
\text { modo fundamentado }\end{array}$ \\
\hline $\begin{array}{l}\text { 4. Capacidade para } \\
\text { tomada de decisão } \\
\text { e para ações } \\
\text { sociopolíticas }\end{array}$ & $\begin{array}{l}\text { Não toma decisões } \\
\text { sobre a QSC }\end{array}$ & $\begin{array}{l}\text { Toma decisões } \\
\text { desconsiderando } \\
\text { consequências, } \\
\text { prós e contras } \\
\text { de ações e } \\
\text { propostas }\end{array}$ & $\begin{array}{l}\text { Toma decisões, } \\
\text { considerando } \\
\text { implicações, } \\
\text { prós e contras e } \\
\text { efeitos de ações } \\
\text { e propostas }\end{array}$ & $\begin{array}{l}\text { Toma decisões } \\
\text { socioambientalmente } \\
\text { responsáveis e parte para a buscando coerência } \\
\text { ação, conhecimentos, valores, } \\
\text { objetivos e condutas }\end{array}$ \\
\hline
\end{tabular}

Fonte: elaborado pelos autores com base em Conrado (2017).

Por fim, acreditamos que a capacitação para ações sociopolíticas e, a longo prazo, a formação de ativistas, que implica transformações de identidades pessoais dos estudantes, podem seguir da estrutura que propomos para a abordagem das QSC em salas de aula ou em comunidades de aprendizagem mais abrangentes. Muito embora não nos pareça necessário que ações sociopolíticas e iniciativas de ativismo estejam sempre presentes no alcance dos objetivos de aprendizagem de conteúdos nas dimensões CPA, nos parece que alcançar esses objetivos pode conduzir a ações sociopolíticas e ativismo, pois, de modo interessante, há uma certa progressão entre dimensões conceituais, procedimentais e atitudinais ao longo dos estágios e níveis da estrutura curricular para ações sociopolíticas, proposta por Hodson $(2004,2011)$ e operacionalizada aqui por nós. Em outras palavras, ao passo em que a aprendizagem de fatos, conceitos e princípios, assim como de procedimentos, técnicas e métodos é ponto de partida e meio, o alcance da aprendizagem de valores, normas e atitudes, culminando idealmente com a prática de ações sociopolíticas e iniciativas duradouras de ativismo, é - ou deveria ser - o ponto de chegada da estrutura curricular.

\section{Considerações finais}

Neste capítulo, apresentamos uma abordagem possível para o ensino de ciências que visa superar problemas da educação tradicional-tecnicista e, ainda, é alinhada com certas vertentes da educação CTSA, aquelas orientadas ao desenvolvimento moral e à explicitação de valores, além daquela voltada ao ativismo sociopolítico, descritas por Pedretti e Nazir (2011). Mais precisamente, propusemos, levando em conta contribuições destas duas vertentes da educação CTSA, uma estrutura de três elementos interconectados (casos que expõe QSC, questões norteadoras e objetivos CPA de aprendizagem) como uma heurística possível para o trabalho com QSC em salas de aula de ciências. 
Parece-nos muito importante que as aplicações de propostas de ensino baseadas em QSC, seguindo a abordagem que aqui expusemos, tenham como meta o fomento de ações sociopolíticas e a formação de ativistas sociopolíticos a longo prazo. Para isso, é importante que os professores de ciências - apesar de todos os contratempos que enfrentam em suas atividades profissionais (relacionados, por exemplo, a excesso de carga horária letiva, más condições de trabalho, baixo engajamento da comunidade escolar e do seu entorno) - estejam preparados para utilizar sua autonomia e as oportunidades de que dispõem para uma formação efetiva de estudantes capazes de se engajarem em causas sociais e ambientais relevantes. Para isto, pode ser muito positivo o estabelecimento de comunidades de prática, para trabalhos colaborativos, entre professores do ensino básico, pesquisadores em educação científica e tecnológica e estudantes de pós-graduação.

Num mundo que já se encontra hoje em crise, as novas gerações enfrentarão grandes desafios socioambientais e os jovens precisam estar preparados. Neste sentido, a educação científica - se realizada com a intenção de preparar nossos jovens para tais desafios, com os compromissos morais que isto exige por parte de todos os atores sociais envolvidos com a educação - pode ser um caminho com muitos frutos a oferecer.

\section{Referências}

ANDRADE, M. A. S. et al. Agrotóxicos como questão sociocientífica na Educação CTSA. REMEA - Revista Eletrônica do Mestrado de Educação Ambiental, Rio Grande, v. 33, n. 1, p. 171-191, 2016.

ARANHA, M. L. de A. Filosofia da Educação. 3. ed. rev. ampl. São Paulo: Moderna, 2006.

AULER, D.; BAZZO, W. A. Reflexões para a implementação do movimento CTS no contexto educacional brasileiro. Ciência \& Educação, Bauru, v. 7, n. 1, p. 1-13, 2001.

AULER, D.; DELIZOICOV, D. Ciência-tecnologia-sociedade: relações estabelecidas por professores de ciências. Revista Electrónica de Enseñanza de las Ciencias, Ourense, v. 5 , n. 2, p. 337-355, 2006 .

BARRETT, S.; PEDRETTI, E. Conflicting orientations to science - technology society - environment education. School Science and Mathematics, Menasha, v. 106, n. 5, p. 21-31, 2006.

BECKERT, C. Dilemas de Ética Ambiental: Estudo de um caso. Lisboa: Sociedade de Ética Ambiental \& Apenas Livros, 2004.

BECKERT, C. Ética. Lisboa: Centro de Filosofia da Faculdade de Lisboa, 2012.

BENCZE, L.; ALSOP, S. Ecojustice through responsibilist Science Education. In: ANNUAL CONFERENCE OF THE CANADIAN SOCIETY FOR THE STUDY OF EDUCATION, 2009, Ottawa. Proceedings... Ottawa: Carleton University, 2009. p. 1-28. 
BENCZE, J. L.; CARTER, L.; KRSTOVIC, M. Science \& technology education for personal, social \& environmental wellbeing: challenging capitalists' consumerist strategies. Revista Brasileira de Pesquisa em Educação em Ciências, Belo Horizonte, v. 14, n. 2, p. 39-56, 2014.

BERGANDI, D. The structural links between ecology, evolution and ethics: the virtuous epistemic circle. Dordrecht: Springer, 2013.

BERGANDI, D.; BLANDIN, P. From the protection of nature to sustainable development: the genesis of an ethical and political oxymoron. Revue d'histoire des sciences, Paris, v. 65, n. 1, jan./jun. 2012.

BERKOWITZ, M. W.; SIMMONS, P. Integrating science education and character education: the role of peer discussion. In: ZEIDLER, D. (Ed.). The role of moral reasoning on socioscientific issues and discourse in science education. Dordrecht, The Netherlands: Kluwer Academic Publishers, 2003. p. 117-138. (Science \& Technology Education Library, 19).

BONJOUR, L.; BAKER, A. Filosofia: textos fundamentais comentados. 2. ed. Porto Alegre: Artmed, 2010.

BORTOLETTO, A.; CARVALHO, W. L. P. Temas sociocientíficos: análise dos processos argumentativos no contexto escolar. In: CARVALHO, L. O. de; CARVALHO, W. L. P. de. (Org.). Formação de professores e questões sociocientíficas no ensino de ciências. São Paulo: Escrituras, 2012. p. 249-270.

BRASIL. Secretaria de Educação Fundamental. Parâmetros curriculares nacionais $\left(1^{a} a\right.$ $4^{a}$ séries). Brasília, DF, 1997.

BRASIL. Secretaria de Educação Fundamental. Parâmetros curriculares nacionais $\left(5^{a} a\right.$ $8^{a}$ séries). Brasília, DF, 1998.

BROWN-ACQUAYE, H. A. Each is necessary and none is redundant: the need for science in developing countries. Science Education, [S.l.], v. 85, n. 1, p. 68-70, 2001.

CARNEIRO, F. F. et al. (Org.). Dossiê ABRASCO: um alerta sobre os impactos dos agrotóxicos na saúde. Rio de Janeiro: EPSJV; São Paulo: Expressão Popular, 2015.

CARTER, L. Sociocultural influences on science education: innovation for contemporary times. Science Education, [S.1.], v. 92, n. 1, p. 165-181, 2008.

CARVALHO, I. N. Uma proposta de critérios para selecionar conteúdos conceituais para o ensino médio de biologia. 2016. 73 f. Dissertação (Mestrado em Ensino, Filosofia e História das Ciências) - Instituto de Física, Universidade Federal da Bahia, Salvador, 2016.

CARVALHO, I. N.; NUNES-NETO, N. F.; EL-HANI, C. N. Como selecionar conteúdos de biologia para o ensino médio? Revista de Educação, Ciências e Matemática, Duque de Caxias, v. 1, n. 1, p. 67-100, 2011.

CLÉMENT, P. Didactic transposition and KVP model: Cconceptions as interactions between Scientific knowledge, Values and Social Practices. In: CONFERENCE OF 
THE EUROPEAN SCIENCE EDUCATION RESEARCH ASSOCIATION, 2006, Braga. Atas... Braga: ESERA Summer School, 2006. p. 9-18.

COLL, C. et al. Los contenidos de la Reforma. Enseñanza y aprendizaje de conceptos, procedimientos y actitudes. Madrid: Santillana, 1992.

COLUCCI-GRAY, L. et al. From scientific literacy to sustainability literacy: an ecological framework for education. Science Education, New York, v. 90, n. 2, p. 227 252, 2006.

CONRADO, D. M. et al. Uso do conhecimento evolutivo na tomada de decisão de estudantes do ensino médio sobre questões socioambientais. Revista Contemporânea de Educação, Rio de janeiro, n. 14, p. 345-368, ago./dez. 2012.

CONRADO, D. M. et al. Evolução e ética na tomada de decisão em questões sociocientíficas. Revista Electrónica de Enseñanza de las Ciencias, Ourense, p. 803-807, 2013. Edição especial.

CONRADO, D. M. et al. Socioscientific issues about bees, pollination and food production in biology teaching. In: CONFERENCE OF THE EUROPEAN SCIENCE EDUCATION RESEARCH ASSOCIATION, 11., 2015, Helsinki. Proceedings... Helsinki, Finlândia: ESERA, 2015. p. 1-4.

CONRADO, D. M. et al. Ensino de biologia a partir de questões sociocientíficas: uma experiência com ingressantes em curso de licenciatura. Indagatio Didactica, Aveiro, v. 8, n. 1, p. 1132-1147, julho, 2016.

CONRADO, D. M. Questões Sociocientíficas na Educação CTSA: contribuições de um modelo teórico para o letramento científico crítico. 2017. 218 f. Tese (Doutorado em Ensino, Filosofia e História das Ciências) - Instituto de Física, Universidade Federal da Bahia, Salvador, 2017.

CONRADO, D. M. Uso de conhecimentos evolutivo e ético na tomada de decisão por estudantes de biologia. 2013. $220 \mathrm{f}$. Tese (Doutorado em Ecologia) - Instituto de Biologia, Universidade Federal da Bahia, Salvador, 2013.

CONRADO, D. M.; CONRADO, I. S. Cientificismo: uma análise crítica do discurso no ensino superior de biologia. In: CONGRESSO IBERO AMERICANO DE INVESTIGAÇÃO QUALITATIVA EM EDUCAÇÃO, 5., 2016, Porto. Atas... Porto: Universidade Lusófona do Porto, 2016a. p. 1054-1059.

CONRADO, D. M.; CONRADO, I. S. Análise crítica do discurso sobre imagens da ciência e da tecnologia em argumentos de estudantes de biologia. Revista de Pesquisa Qualitativa, São Paulo, v. 4, n. 5, p. 218-231, 2016 b.

CONRADO, D. M.; EL-HANI, C. N. Formação de cidadãos na perspectiva CTS: reflexões para o ensino de ciências. In: SIMPÓSIO NACIONAL DE ENSINO DE CIÊNCIA E TECNOlOGIA, 2., 2010, Ponta Grossa. Atas... Ponta Grossa: UTFPR, 2010. CONRADO, D. M.; EL-HANI, C. N.; NUNES-NETO, N. F. Sobre a ética ambiental na formação do biólogo. REMEA-Revista Eletrônica do Mestrado em Educação Ambiental, Rio Grande, v. 30, n. 1, p. 120-139, jan./jun. 2013. 
CONRADO, D. M.; NUNES-NETO, N. F.; EL-HANI, C. N. Análise de argumentos em uma questão sociocientífica no ensino de biologia. In: ENCONTRO NACIONAL DE ENSINO DE BIOLOGIA, 6.; ENCONTRO REGIONAL DE ENSINO DE BIOLOGIA DA REGIONAL 3, 8., 2016, Maringá. Anais... Maringá: Universidade Estadual de Maringá, 2016.

CONRADO, D. M.; NUNES-NETO, N. F. Dimensões do conteúdo em questões sociocientíficas no ensino de ecologia. In: ENCONTRO NACIONAL DE EDUCAÇÃO EM CIÊNCIAS, 16., 2015, Lisboa. Atas... Lisboa: Instituto de Letras, Universidade de Lisboa, 2016. p. 432-435, 2015.

COPI, I. Introdução à lógica. São Paulo: Mestre Jou, 1968.

DRIVER, R.; NEWTON, P.; OSBORNE, J. Establishing the norms of scientific argumentation in classrooms. Science Education, New York, v. 84, n. 3, p. 287-312, 2000 .

FELIPE, S. T. Antropocentrismo, sencientismo e biocentrismo: perspectivas éticas abolicionistas, bem-estaristas e conservadoras e o estatuto de animais não-humanos. Revista Páginas de Filosofia, São Bernardo do Campo, v. 1, n. 1, p. 2-30, jan./jul. 2009.

FERNANDES, C. S.; STUANI, G. M. Agrotóxicos no ensino de ciências: uma pesquisa na educação do campo. Educação \& Realidade, Porto Alegre, v. 40, n. 3, p. 745-762, 2015.

FERREIRA, T. A. S. et al. Ensino de análise do comportamento com o uso de questões sociocientíficas: um caso sobre a medicalização da vida. Indagatio Didactica, Aveiro, v. 8 , n. 1, p. 1481-1497, jul. 2016.

FOUREZ, G. A construção das ciências: introdução à filosofia e à ética das ciências. São Paulo: UNESP, 1995.

FOUREZ, G. Educar: docentes, alunos, escolas, éticas, sociedades. Aparecida, SP: Idéias e Letras, 2008.

FREIRE, P. Pedagogia da autonomia: saberes necessários à prática educativa. São Paulo: Paz e Terra, 1996.

FULLICK, P.; RATCLIFFE, M. (Ed.). Teaching ethical aspects of science. Totton: Bassett Press, 1996.

GIROUX, H. A. Theory and resistance in education. London: Bergin \& Garvey, 2001.

GOERGEN, P. Educação moral hoje: cenários, perspectivas e perplexidades. Educação \& Sociedade, Campinas, v. 28, n. 100, p. 737-762, 2007. Edição especial.

GUIMARÃES, A. G.; CARVALHO, W. L. P. de; OLIVEIRA, M. S. Raciocínio moral na tomada de decisões em relação a questões sociocientíficas: o exemplo do melhoramento genético humano. Ciência \& Educação, Bauru, v. 16, n. 2, p. 465-477, 2010. 
HEMPEL, M. Ecoalfabetización: el conocimiento no es suficiente. In: MASTNY, L. (Ed.). Gobernar para la sostenibilidad: la situación del mundo 2014. Barcelona: Icaria editorial, 2014. p. 79-93.

HODSON, D. Going Beyond STS: towards a curriculum for sociopolitical action. The Science Education Review, [S.1.], v. 3, v. 1, p. 2-7, 2004.

HODSON, D. Looking to the future: building a curriculum for social activism. Rotterdam: Sense Publishers, 2011.

HODSON, D. Don't be nervous, don't be flustered, don't be scared: be prepared. Canadian Journal of Science, Mathematics and Technology Education, Canadá, v. 13, n. 4, p. 313-331, 2013.

HURTSHOUSE, R. Normative Virtue Ethics. In: SHAFER-LANDAU, R. (Ed.). Ethical theory: an anthology. $2^{\text {nd }}$. Oxford: Wiley-Blackwell, 2013. p. 645-652.

JIMÉNEZ-ALEIXANDRE, M. P.; PEREIRO-MUÑOZ, C. Knowledge producers or knowledge consumers? Argumentation and decision making about environmental management. International Journal of Science Education, London, v. 24, n. 11, p. 11711190, 2002.

JIMÉNEZ-ALEIXANDRE, M. P.; FREDERICO-AGRASO, M. A argumentação sobre questões sociocientíficas: processos de construção e justificação do conhecimento em sala de aula. Educação em Revista, Belo Horizonte, v. 43, n. 1, p. 13-33, 2006.

KENTLY, F. D. Comparison of hidden curriculum theories. European Journal of Educational Studies, Bucharest, v. 1, n. 2, p. 83-88, 2009.

KERCKHOFF, A. S.; REIS, G. Responsible Stewards of the Earth: narratives of youth activism in high school (science). In: BENCZE, L.; ALSOP, S. (Ed.). Activist science and technology education. Dordrecht: Springer Netherlands, 2014. p. 465-476.

KNIGHT, J. K.; WOOD, W. B. Teaching more by lecturing less. The American Society for Cell Biology, Bethesda, v. 4, p. 298-310, 2005.

KRSTOVIC, M. Preparing students for self-directed research-informed actions on socioscientific issues. In: BENCZE, L.; ALSOP, S. (Ed.). Activist science and technology education. Dordrecht: Springer Netherlands, 2014. p. 399-417.

LACEY, H. Valores e atividade científica 2. São Paulo: Associação Filosófica Scientiae Studia: Ed. 34, 2010.

LAYTON, D. Revaluing the T in STS. International Journal of Science Education, London, v. 10, n. 4, p. 367-378, 1988.

LEOPOLD, A. The land ethic. In: LIGHT, A.; ROLSTON III, H. (Ed.). Environmental Ethics: an anthology. Malden-MA: Wiley-Blackwell, 2003. p. 38-46.

LEVINSON, R. Towards a theoretical framework for teaching controversial socioscientific Issues. International Journal of Science Education, London, v. 28, n. 10, p. 1201-1224, Aug. 2006. 
LIMA, G. Z. de; LINHARES, R. E. C. Escrever bons problemas. Revista Brasileira de Educação Médica, Rio de Janeiro, n. 32, v. 2, p. 197-201, 2008.

LODI, L. H.; ARAÚJO, U. F. Ética e cidadania e educação: escola, democracia e cidadania. In: Ética e cidadania: construindo valores na escola e na sociedade. Brasília, DF: Ministério da Educação, Secretaria de Educação Básica, 2007. p. 69-84.

LUCKESI, C. C. Filosofia da educação. 3. ed. São Paulo: Cortez, 2011.

SILVA, J. M. da. Ética prática: contributos para as Políticas da Água. Lisboa: Sociedade de Ética Ambiental / Apenas Livros, 2003. (Breviário de Ética Ambiental, n. 8).

MARTÍN, M. M. Conocer, manejar, valorar, participar: los fines de una educación para la ciudadanía. Revista Iberoamericana de Educación, Madrid, n. 42, p. 69-83, 2006.

MARTÍNEZ PÉREZ, L. F. M. Questões sociocientíficas na prática docente: ideologia, autonomia e formação de professores. São Paulo: UNESP, 2012.

MARTÍNEZ PÉREZ, L. F. M.; CARVALHO, W. L. P. Contribuições e dificuldades da abordagem de questões sociocientíficas à prática de professores de ciências. Educação e Pesquisa, São Paulo, v. 38, p. 728-742, 2012.

MARTÍNEZ PÉREZ, L. F.; PARGA LOZANO, D. L. La emergencia de las cuestiones sociocientíficas en el enfoque CTSA. Góndola, Enseñanza y Aprendizaje de las Ciencias, Bogotá, v. 8, n. 1, p. 23-35, 2013.

MARTÍNEZ PÉREZ, L. F.; VILLAMIZAR FÚQUENE, D. P. Unidades didácticas sobre cuestiones socio científicas: construcciones entre la escuela y la universidad. Bogotá: Colciencias; Alternaciencias: Universidad Pedagógica Nacional, 2014.

MATTHEWS, M. R. Science teaching: the role of History and Philosophy of Science. Routledge: London, 1994.

MEADOWS, D. H. The limits to growth. New York: Universe Books, 1972.

NORTON, B. Searching for sustainability: interdisciplinary essays in the Philosophy of Conservation Biology. Cambridge: Cambridge University Press, 2003.

NOSS, R. F. Values are a good thing in Conservation Biology. Conservation Biology, Boston, v. 21, n. 1, p. 18-20, 2007.

OLIVEIRA, R. J. O ensino das ciências e a ética na escola: interfaces possíveis. Química Nova na Escola, São Paulo, v. 32, n. 4, p. 227-232, 2010.

OSBORNE, J.; EDURAN, S.; SIMON, S. Enhancing the quality of argument in school science. Journal of Research in Science Teaching, New York, v. 41, n. 10, p. 994-1020, 2004.

PEDRETTI, E.; NAZIR, J. Currents in STSE education: mapping a complex field, 40 years on. Science Education, New York, v. 95, n. 4, p. 601-626, 2011.

PEDRETTI, E.; FORBES, J. STSE education: from curriculum rhetoric to classroom reality. Orbit, v. 31, n. 3, p. 39-41, 2000. 
PINZANI, A. Democracia versus tecnocracia: apatia e participação em sociedades complexas. Lua Nova, São Paulo, n. 89, p. 135-168, 2013.

RACHELS, J. Introducción a la filosofía moral. México: Fondo de Cultura Económica, 2006.

RACHELS, J. Problemas da filosofia. 2. ed. Lisboa: Gradiva, 2010. (Coleção Filosofia Aberta, 19).

RACHELS, J.; RACHELS, S. A coisa certa a fazer: leituras básicas sobre filosofia moral. 6. ed. Porto Alegre: AMGH, 2014.

RATCLIFFE, M.; GRACE, M. Science education for citizenship: teaching socio-scientific issues. Maidenhead: Open University Press, 2003.

REGAN, T. Animal Rights and Environmental Ethics. In: BERGANDI, D. (Ed.). The Structural Links between ecology, evolution and ethics: the virtuous epistemic circle. Dordrecht: Springer, 2013. p. 117-126.

REIS, P. Factors of success regarding classroom discussions of SSI: a cross-case study. Les Dossiers des Sciences de L'éducation, Toulouse, n. 29, p. 67-80, 2013.

REIS, P. Acción socio-política sobre cuestiones socio-científicas: reconstruyendo la formación docente y el currículo. Revista Uni-pluri/versidad, Lisboa, v. 14, n. 2, 2014.

REIS, G.; NG-A-FOOK, N.; GLITHERO, L. Provoking ecojustice-taking citizen science and youth activism beyond the school curriculum. In: MUELLER, M. P.; TIPPINS, D. J. (Ed.). EcoJustice, citizen science and youth activism: situated tensions for Science Education. Cham, Switzerland: Springer, 2015. p. 39-61.

SÁ, L. P.; QUEIROZ, S. L. Promovendo a argumentação no ensino superior de química. Química Nova, São Paulo, v. 30, n. 8, p. 2035-2042, 2007.

SÁ, L. P.; QUEIROZ, S. L. Estudo de casos no ensino de química. Campinas: Átomo, 2010.

SADLER, T. D. Moral and ethical dimensions of socioscientific decision-making as integral components of science literacy. Science Educator, Glastonbury, v. 13, p. 39-48, 2004a.

SADLER, T. D. Moral sensitivity and its contribution to the resolution of socioscientific issues. Journal of Moral Education, Abingdon, v. 33, n. 3, p. 339-358, 2004b.

SADLER, T. D.; BARAB, S. A.; SCOTT, B. What do students gain by engaging in socioscientific inquiry? Research in Science Education, Dordrecht, v. 37, n. 4, p. 371-391, 2007.

SADLER, T. D.; ZEIDLER, D. L. The morality of socioscientific issues: construal and resolution of genetic engineering dilemmas. Science Education, New York, v. 88, n. 1, p. 4-27, 2004. 
SANTOS, W. L. P. dos. Scientific literacy: a freirean perspective as a radical view of humanistic science education. Science Education, New York, v. 93, n. 2, p. 361-382, 2009.

SANTOS, W. L. P. Educação CTS e cidadania: confluências e diferenças. Amazônia, Belém, v. 9, n. 17, p. 49-62, 2012.

SANTOS, W. L. P. dos; MORTIMER, E. F. Uma análise de pressupostos teóricos da abordagem C-T-S (Ciência-Tecnologia-Sociedade) no contexto da educação brasileira. Ensaio Pesquisa em Educação em Ciências, Belo Horizonte, v. 2, n. 2, p. 133-162, 2002.

SARMENTO, A. C. de H. et al. Investigando princípios de design de uma sequência didática sobre metabolismo energético. Ciência \& Educação, Bauru, v. 19, n. 3, p. 573598, 2013.

SAVIANI, D. Política e educação no Brasil: o papel do congresso nacional na legislação do ensino. Campinas: Autores Associados, 1987.

SAVIN-BADEN, M.; MAJOR, C. H. Foundations of problem-based learning: Great Britain: MPG Books: Open University Press, 2004.

SILVA, S. M. B.; SANTOS, W. L. P. dos. Questões sociocientíficas e o lugar da moral nas pesquisas em ensino de ciências. Interacções, Lisboa, v. 10, n. 31, p. 124-148, 2014.

SINGER, P. (Ed.). Compendio de ética. Madrid: Alianza Editorial, 2004.

SINGER, P. Libertação Animal. Porto Alegre: Lugano, 2010.

SINGER, P. The Expanding circle: ethics, evolution, and moral progress. Princeton: Princeton University Press, 2011.

SOLBES, J. Contribución de las cuestiones sociocientíficas al desarrollo del pensamiento crítico (II): Ejemplos. Revista Eureka sobre Enseñanza y Divulgación de La Ciencias, Puerto Real, v. 10, n. 2, p. 148-158, 2013.

SOLOMON, J. Teaching science, technology and society. Buckingham: Open University Press, 1993.

TAN, M. Science teacher activism: the case of environmental education. Journal for Activist Science \& Technology Education, Toronto, v. 1, n. 1, p. 32-43, 2009.

TORRES-MERCHÁN, N. Y. El abordaje de situaciones contextuales para la solución de problemas y la toma de decisiones. Zona Próxima, Barranquilla, n. 14, p. 126-141, 2011.

VAZ, S. A. G.; DELFINO, Â. Manual de ética ambiental. Lisboa: Universidade Aberta, 2010 .

VELLOSO, A. M. S. et al. Argumentos elaborados sobre o tema "corrosão" por estudantes de um curso superior de química. Revista Electrónica de Enseñanza de las Ciencias, Ourense, v. 8, n. 2, p. 593-616, 2009. 
VILCHES, A.; GIL-PÉREZ, D.; PRAIA, J. De CTS a CTSA: educação por um futuro sustentável. In: SANTOS, W. L. P. dos; AULER, D. (Org.). CTS e educação científica: desafios, tendências e resultados de pesquisas. Brasília: UnB, 2011. p. 161-184.

VILLA, A.; POBLETE, M. Aprenizaje basado en competencias: una propuesta para la evaluación de las competencias genéricas. Bilbao: Universidad de Deusto, 2007.

VON LINSINGEN, I. Perspectiva educacional CTS: aspectos de um campo em consolidação na América Latina. Ciência \& Ensino, Campinas, v. 1, p. 1-19, nov. 2007. Edição especial.

VON LINSINGEN, I.; CASSIANI, S. Educação CTS em perspectiva discursiva: contribuições dos Estudos Sociais da Ciência e da Tecnologia. Redes, Buenos Aires, v. 16, n. 31, p. 163-182, 2010.

WORLD WILDLIFE FUND. WWF. Living Planet Report 2014: Summary. Gland, 2014. WARBURTON, N. Elementos básicos de filosofia. 2. ed. Lisboa: Gradiva, 2007. ZABALA, A. A prática educativa: como ensinar. Porto Alegre: Artes Médicas Sul, 1998. ZABALA, A.; ARNAU, L. Como aprender e ensinar competências. Porto Alegre: Artmed, 2010.

ZEIDLER, D. L.; KEEFER, M. The role of moral reasoning and the status of socioscientific issues in science education. In: ZEIDLER, D. L. (Ed.). The role of moral reasoning in socioscientific issues and discourse in science education. Dordrecht: Kluwer, 2003. p. 7-38.

ZEIDLER, D. et al. Beyond STS: A Research-based Framework for Socioscientific Issues Education. Science Education, New York, n. 89, p. 357-377, 2005.

ZIMAN, J. The rationale for STS is in the approach. In: SOLOMON, J.; AIKENHEAD, G. (Ed.). STS education: international perspectives on reform. New York: Teachers College Press, 1994. p. 21-31. 